\title{
Continuous vegetation record of the Greater Cape Floristic Region (South Africa) covering the past 300000 years (IODP U1479)
}

\author{
Lydie M. Dupont ${ }^{1, \mathrm{a}}$, Xueqin Zhao ${ }^{1, \mathrm{~b}}$, Christopher Charles $^{2}$, John Tyler Faith ${ }^{3,4}$, and David Braun ${ }^{5,6}$ \\ ${ }^{1}$ MARUM - Center for Marine Environmental Sciences, University of Bremen, 28359 Bremen, Germany \\ ${ }^{2}$ The Scripps Institution of Oceanography, University of California San Diego, La Jolla, CA 92037, USA \\ ${ }^{3}$ Natural History Museum of Utah, University of Utah, Salt Lake City, UT 84108, USA \\ ${ }^{4}$ Department of Anthropology, University of Utah, Salt Lake City, UT 84112, USA \\ ${ }^{5}$ Center for the Advanced Study of Human Paleobiology, George Washington University, Washington DC 20052, USA \\ ${ }^{6}$ Department of Archaeology, University of Cape Town, Rondebosch 7701, South Africa \\ ${ }^{a}$ present address: Hendrik Werkmanstr. 5, 1061 VA Amsterdam, Netherlands \\ b present address: College of Marine Sciences, Shanghai Ocean University, Shanghai, China
}

Correspondence: Lydie M. Dupont (dupont@uni-bremen.de)

Received: 12 July 2021 - Discussion started: 19 July 2021

Revised: 27 November 2021 - Accepted: 29 November 2021 - Published: 6 January 2022

\begin{abstract}
The Greater Cape Floristic Region (GCFR) of South Africa is a biodiversity hotspot of global significance, and its archeological record has substantially contributed to the understanding of modern human origins. For both reasons, the climate and vegetation history of southwestern South Africa is of interest to numerous fields. Currently known paleoenvironmental records cover the Holocene, the last glacial-interglacial transition and parts of the last glaciation but do not encompass a full glacial-interglacial cycle. To obtain a continuous vegetation record of the last Pleistocene glacial-interglacial cycles, we studied pollen, spores and micro-charcoal of deep-sea sediments from IODP Site U1479 retrieved from SW of Cape Town. We compare our palynological results of the Pleistocene with previously published results of Pliocene material from the same site. We find that the vegetation of the GCFR, in particular fynbos and afrotemperate forest, responds to precessional forcing of climate. The micro-charcoal record confirms the importance of fires in the fynbos vegetation. Ericaceae-rich and Asteraceaerich types of fynbos could extend on the western part of the Paleo-Agulhas Plain (PAP), which emerged during periods of low sea level of the Pleistocene.
\end{abstract}

\section{Introduction}

Southwestern South Africa is a fascinating region for both its unique flora and for its role in our knowledge of the origin of modern human behavior (Fig. 1). The Greater Cape Floristic Region (GCFR) harbors an exceptionally rich flora with many endemics, which has been relatively stable since the late Miocene (Linder, 2003; Dupont et al., 2011). The region also has a very rich archeological record (e.g., Henshilwood et al., 2002, 2011; Mackay et al., 2014; Marean et al., 2014), especially of the last climate cycle (from 150000 years ago). The paleoenvironmental records of the GCFR sites covering at least part of the last glaciation are varied and detailed. They include stable carbon and oxygen isotope records of speleothems (Talma and Vogel, 1992; BarMatthews et al., 2010; Braun et al., 2019, 2020), stable isotopes from hyrax middens (Chase et al., 2011, 2012, 2017, 2018, 2019), mammal bone assemblages (Klein, 1983; Avery, 1982; Faith, 2013; Klein and Cruz-Uribe, 2016, 2000; Nel and Henshilwood, 2016; Nel et al., 2018; Forrest et al., 2018), microwear patterns and stable isotopes of fossil teeth (Copeland et al., 2016; Sealy et al., 2016, 2020; Hodgkins et al., 2020; Williams et al., 2020), charcoal (Cartwright and Parkington, 1997; Cowling et al., 1999; Cartwright, 2013; Parkington et al., 2000), phytoliths (Esteban et al., 2018, 
2020), and pollen (Meadows and Sudgen, 1991; Chase and Meadows, 2007; Scott and Woodborne, 2007a, b; Meadows et al., 2010; Quick et al., 2011, 2015, 2016; Valsecchi et al., 2013; Chase and Quick, 2018; Scott and Neumann, 2018). The list is by no means comprehensive.

After considerable efforts from various disciplines, detailed maps of the now submerged continental shelf area south of South Africa have been constructed (Cleghorn et al., 2020), providing a view of the ecosystems on the PaleoAgulhas Plain (PAP), which was largely exposed during the Last Glacial Maximum (Marean et al., 2020). The inferred glacial vegetation of the PAP is based on vegetation modeling (Cowling et al., 2020) using geological and soil maps (Cawthra et al., 2020) in connection with regional climate modeling (Engelbrecht et al., 2019). A wide landscape emerged divided by broad river systems with diverse fynbos types in the western and southern part of the PAP. The central portion of the PAP was probably dominated by open grasslands.

Despite the wealth of information, a synthetic understanding of vegetation and climate of the past glacial-interglacial cycle remains elusive. This uncertainty stems from a combination of problems including (i) uneven spatiotemporal sampling coupled with a substantial amount of poorly understood spatial variation (e.g., Chase et al., 2017, 2018); (ii) records that reflect changes over a limited spatial extent and over relative short periods of time (e.g., Chase, 2010; Marean et al., 2014); (iii) reliance on a diversity of different proxies, not all of which directly provide information about the climate or vegetation parameters of interest (Chase et al., 2013); (iv) seemingly contradictory lines of evidence (e.g., Avery, 1982; Faith, 2013); and (v) conflicting interpretations of the evidence (e.g., Faith et al., 2019; Thackeray, 2020).

To provide a regional framework of climate and vegetation dynamics across multiple glacial-interglacial cycles, we report a record of the vegetation in the GCFR using pollen and spores recovered from deep-sea sediments of IODP Site U1479 (Fig. 1), which were retrieved offshore almost $160 \mathrm{~km} \mathrm{SW}$ of Cape Town (Hall et al., 2017). While the terrestrial paleontological and paleobotanical records mostly reflect the environment of a relatively limited spatial area and cover relatively short stretches in time (Marean et al., 2014), marine sediments collect pollen and spores from a wide terrestrial area and thus record an integrated regional signal (Dupont, 2011). Moreover, the marine sediments have a chronology that allows the assessment of vegetation dynamics with respect to orbital forcing and other climatic proxy records that are tied to the same chronology. The sediments of IODP Site U1479 demonstrably provide a continuous signal extending from the late Quaternary down to the Pliocene. Our record enables us to continuously follow regional vegetation change in the GCFR over the past 300000 years (kyr) at a temporal resolution of ca. 3 kyr. We investigate the vegetation response to climate changes and sea level fluctuations of the middle to late Pleistocene climate cycles.
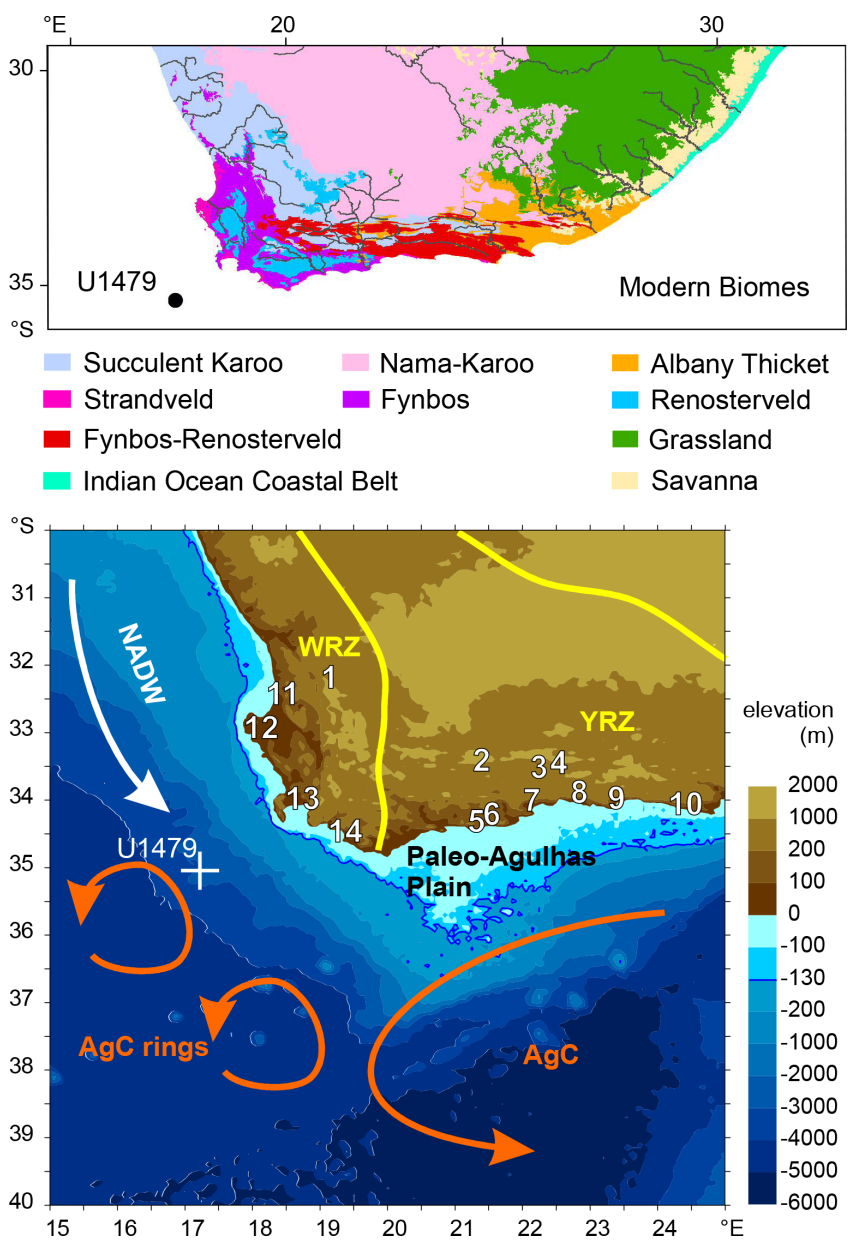

Figure 1. Modern vegetation of South Africa (top) south of $30^{\circ} \mathrm{S}$, with main rivers draining to the ocean (Mucina and Rutherford, 2006) and the location of IODP Site U1479 (dot). Map (bottom) of the Southern and Western Cape as well as sites mentioned in the text. The directions of the North Atlantic Deep Water (NADW), the Agulhas Current $(\mathrm{AgC})$, the Agulhas rings ( $\mathrm{AgC}$ rings) and PaleoAgulhas Plain (PAP) are indicated over the ocean; on the continent the winter rainfall zone (WRZ) and the year-round rainfall zone (YRZ) are denoted. The location of Site U1479 is denoted by the white cross. 1. Cederberg Mountains, 2. Seweweekspoort, 3. Boomplaas and Cango caves, 4. Efflux Cave, 5. Blombos Cave, 6. Still Bay (Rietvlei), 7. Pinnacle Point, 8. wilderness embayment (Vankervelsvlei), 9. Nelson Bay Cave, 10. Klasies River Mouth Cave, 11. Elands Bay Cave, 12. Hoedjiespunt, 13. Swartklip (False Bay), 14. Die Kelders Cave.

\section{Modern climate and vegetation}

The modern climate of South Africa is dominated by the atmospheric South Atlantic high-pressure system in the southwest and the easterly flow from the Indian Ocean (Tyson and Preston-Whyte, 2000). This results in a climate pattern over South Africa that can be divided according to its rainfall regime (Fig. 2) (Hijmans et al., 2005; Chase and Meadows, 2007). In most of South Africa, precipitation falls during the 


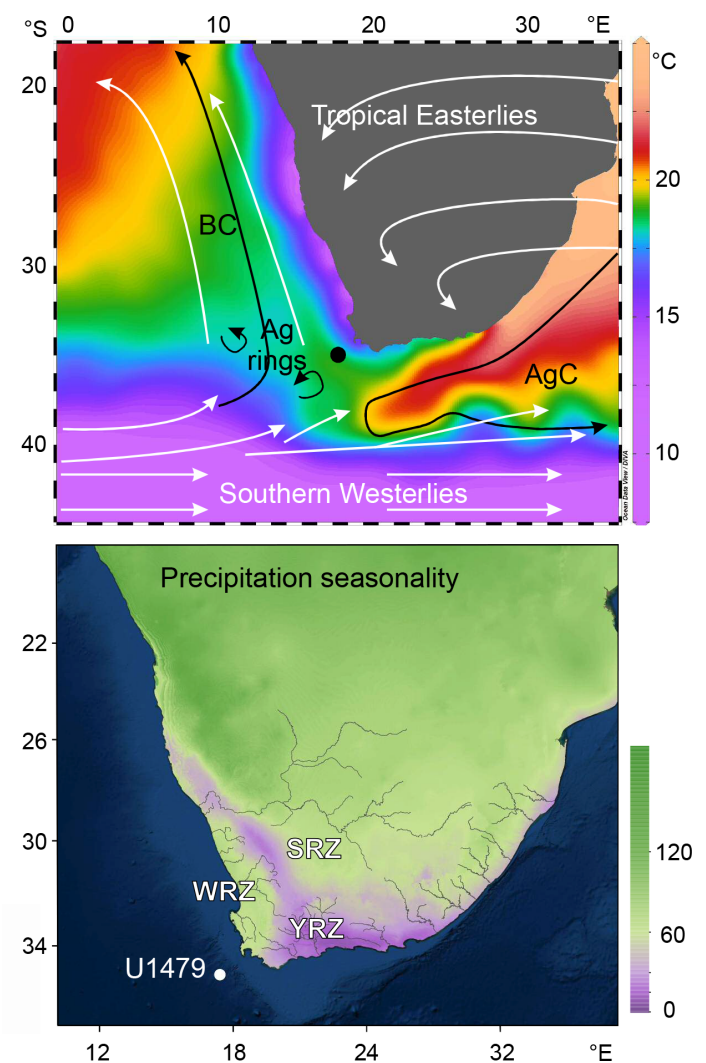

Figure 2. Top: map of the modern atmosphere and surface ocean circulations with modern sea surface temperatures (World Ocean Atlas 2013, Boyer et al., 2013) and the location of IODP Site U1479 (dot). BC, Benguela Current; AgC, Agulhas Current; Ag rings, Agulhas rings. Bottom: precipitation seasonality (mean monthly precipitation coefficient of variation) showing three rainfall zones in southern Africa derived from WorldClim version 1.3 (Hijmans et al., 2005). WRZ, winter rainfall zone; SRZ, summer rainfall zone; YRZ, year-round rainfall zone (lilac).

summer months (October to March; summer rainfall zone, SRZ), while in the southwestern part of the subcontinent, westerly winds bring precipitation during the winter months (April to September; winter rainfall zone, WRZ). A transitional region located between these two regions receives rain in all seasons (year-round rainfall zone, YRZ). Furthermore, sea surface temperatures influence the climate, in particular the warm waters of the Agulhas Current and the cold waters of the Benguela upwelling system.

While modern rainfall in the SRZ is modulated by the sea surface temperature (SST) of the Indian Ocean (Reason and Mulenga, 1999), southwestern African precipitation is affected by South Atlantic SST and the Agulhas Current. Winter rainfall in the southwestern Cape comes mainly with cold fronts, especially if the westerlies have a northern position over the southern tip of Africa. Warm Atlantic SSTs provide more moisture to be advected into the continent. Moisture from the warm Agulhas waters recirculates over southernmost Africa (Reason et al., 2003).

The situation on the south coast is more complicated. Both tropical-temperate troughs from the east and frontal systems from the west influence the balance between WRZ and YRZ. According to Engelbrecht et al. (2015), modern precipitation along the south coast is contributed by cut-off lows $(16 \%$ of annual rainfall), ridging high-pressure systems (46\%) and tropical-temperate troughs $(28 \%)$. In addition, the Agulhas Current influences the climate of the coastal area (Jury et al., 1993), which on longer timescales could have propagated climate signals from the tropics to the Southern Cape coast (Chase and Quick, 2018).

The GCFR is situated in the WRZ and YRZ and encompasses three biomes: fynbos (including fynbos sensu stricto, renosterveld and strandveld), succulent Karoo and Albany thicket (Fig. 1). The semi-desert vegetation of the Nama Karoo grows in the SRZ northeast of the GCFR (Mucina and Rutherford, 2006). Fynbos (from the Afrikaans word meaning "fine bush") consists of fine-leaved evergreen shrubs growing on nutrient-poor soils of the southwestern Cape with annual precipitation between 600 and $80 \mathrm{~mm}$. It is extraordinarily rich in Erica species. In addition to Ericaceae other important families are Asteraceae, Rhamnaceae, Thymelaeaceae, Rutaceae, Proteaceae and the almost endemic Bruniaceae. The most important graminoids are the Restionaceae (Cape reeds), but Cyperaceae (sedges) and Poaceae (grasses) also occur (Rebelo et al., 2006). Renosterveld is dominated by evergreen asteraceous shrubs, notably Elytropappus rhinocerotis (renosterbos). Cliffortia (Rosaceae) and Anthospermum (Rubiaceae) are important elements and so are species of Fabaceae and Malvaceae. Along the coast the littoral thicket, called strandveld, shrubs and small trees are present that have broader leaves than the shrubs of the fynbos. In the thicket, apart from the trees (Celastraceae, Diospyros, Morella) Restionaceae are abundant (Rebelo et al., 2006). The succulent Karoo vegetation contains many dwarf leaf succulents of Aizoaceae and Crassulaceae growing in the drier parts of the GCFR, in which sparse rain (average $170 \mathrm{~mm} \mathrm{yr}^{-1}$ ) falls predictably during the winter months. Furthermore, the vegetation includes Asteraceae, Amaranthaceae, Euphorbiaceae and Zygophyllaceae but few grasses (Mucina et al., 2006). Albany thicket grows in the eastern part of the GCFR and is probably less relevant for this study.

On the south- and east-facing slopes of the Cape Fold Belt Mountains and along the south coast afrotemperate forest grows, which has a multi-layered canopy and occurs in the deep gorges. Podocarpaceae species (Podocarpus latifolius and Afrocarpus falcatus) are important constituents. Afrotemperate forest needs mean annual rainfall of at least $525 \mathrm{~mm}$ (Mucina and Geldenhuys, 2006). In both fynbos and renosterveld, burning of the vegetation is important and its regeneration depends on fire. Fires are less important in the succulent Karoo and afrotemperate forest due to insufficient 
fuel in the former and too much moisture in the latter (Whitlock et al., 2010).

\section{Material and methods}

\subsection{Site location, composite depth, chronology}

IODP Site U1479 $\left(35^{\circ} 04^{\prime} \mathrm{S}, 17^{\circ} 24^{\prime} \mathrm{E}\right)$ is located ca. $160 \mathrm{~km}$ southwest of Cape Town, South Africa, on a $30 \mathrm{~km}$ wide ridge rising ca. $200 \mathrm{~m}$ above its surroundings on the middle to lower western slope of the Agulhas Bank in the Cape Basin at a water depth of ca. $2615 \mathrm{~m}$ below sea level (Fig. 1, Hall et al., 2017). The seafloor at the site is bathed in North Atlantic Deep Water, while the surface ocean is influenced by the waters of the Agulhas Current, which retroflects from the Agulhas Bank at the southern tip of Africa and then flows eastwards as the Agulhas Return Current. The Agulhas retroflection occurs east of Site U1479 (Hall et al., 2017), but the phenomenon is characterized by the frequent shedding of warm core rings that pass directly over the site. A principal motivation for drilling Site U1479 was to develop a long record of this Agulhas "leakage" of warm and salty Indian Ocean water into the South Atlantic Ocean.

The sediments at Site U1479 are mostly pelagic and the terrigenous component is low but variable (quartz: $6 \pm 5 \%$; clay: $8 \pm 2 \%$ ). Nine holes were cored at Site U1479 to ensure a continuous sedimentary sequence spanning more than $230 \mathrm{~m}$ (early Pliocene to Holocene). A spliced composite record from these nine holes was created from multiple physical properties measured shipboard, most notably sediment color (Hall et al., 2017). Sampling for various micro-paleontological and geochemical purposes was conducted along this spliced composite. The chronostratigraphic framework for this splice derives from the oxygen isotopic composition of the benthic foraminifera Planulina wuellerstorfi, measured at $5 \mathrm{~cm}$ intervals at the Scripps Institution of Oceanography using a Thermo MAT253 equipped with a Kiel IV carbonate preparation device. Analytical uncertainty is less than $0.08 \%$. The details of the full record (including the accompanying carbon isotopic analyses) are presented elsewhere (Hines et al., 2021), but the interval corresponding to the last $300 \mathrm{kyr}$ is displayed in Figs. 3 and 4.

The core material from the shipboard splice was largely exhausted by this initial sampling. However, in the upper part of the sequence, there was sufficient overlap among the cores recovered to construct a parallel spliced composite record. Accordingly, we selected samples from holes B, C, G and H to obtain a record of the past $300 \mathrm{kyr}$ with a time step of 2 to $4 \mathrm{kyr}$. Holes were correlated using the green channel values of the shipboard data (Fig. 3 and Fig. S1 in the Supplement). We first plotted the green values of cores B1, C2, G1, H1, H2 and $\mathrm{I} 1$ against the published composite depth (splice). Because the hole compositing approach involves single depth offsets for an entire core (ca. $10 \mathrm{~m}$ in length), it does not account for variable stretching and compression of cored in- tervals relative to their stratigraphic correlates in a different spliced composite. In order to make use of the stratigraphic information on oxygen isotopes measured in the shipboard splice, it is necessary to account for this relative distortion in our alternative splice. The depth of core B1 had to be shifted $46 \mathrm{~cm}$ upwards and stretched by a factor of 1.184 to obtain the best stratigraphic correlation with the shipboard splice. Depths of core $\mathrm{H} 1$ only had to be stretched by a factor of 1.127 to achieve optimal stratigraphic correlation (Supplement Fig. S1).

The chronology for the spliced composite can be established in a number of ways, including transferal of common oxygen isotopic chronologies (e.g., LR04 stack; Lisiecki and Raymo, 2005). However, the chronology we employ here uses a more independent approach. Throughout the ca. $6 \mathrm{Myr}$ long record of Site U1479, sediment color displays strong cyclical variability at frequencies associated with orbital (climatic) precession, and the discrimination of these cycles with depth suggests a modulation of amplitude similar to that of precession. Discrete shipboard measurements and XRF (nondestructive X-ray fluorescence analysis of major and minor elements by scanning the surface of split sediment cores) scanning indicate that the sediment color essentially monitors variable carbonate content, but the orbital tuning approach requires no assumption about the actual mechanism through which orbital variability paces the carbonate variability. The most detailed orbital tuning typically requires either the manual anchoring of the ordinal points of every cycle or else the use of deterministic or probabilistic mapping techniques (e.g., Lin et al., 2014). However, under the circumstances, the transfer of such higher-order assumptions from the shipboard splice to the alternative splice used for pollen analysis would introduce additional errors and therefore be of debatable merit. Thus, for this work, we simply adopt the minimum number of chronological anchor points necessary to achieve significant correlation between sediment color and precession. The resulting age-depth model and sedimentation rates for the past $350 \mathrm{kyr}$ are plotted in Fig. 4, illustrating that sedimentation rates implied by orbital tuning have been relatively stable around a mean of ca. $4.5 \mathrm{~cm} \mathrm{kyr}^{-1}$ since ca. $300 \mathrm{ka}$. Furthermore, we can use the oxygen isotopic record to cross-check the orbitally tuned chronology against the LR04 global isotope chronology (Lisiecki and Raymo, 2005); the differences are generally within the error of $\pm 4 \mathrm{kyr}$ for the past million years stated for the LR04 stack (Past Interglacials Working Group of PAGES, 2016), though there is isolated divergence in discrete intervals such as the penultimate deglaciation (Fig. 4). At the top of the sequence, the later Holocene is probably missing. In any case, through either approach - oxygen isotopic or orbital tuning - the sediment chronology clearly resolves the suborbital variability of the last three ice age cycles. 


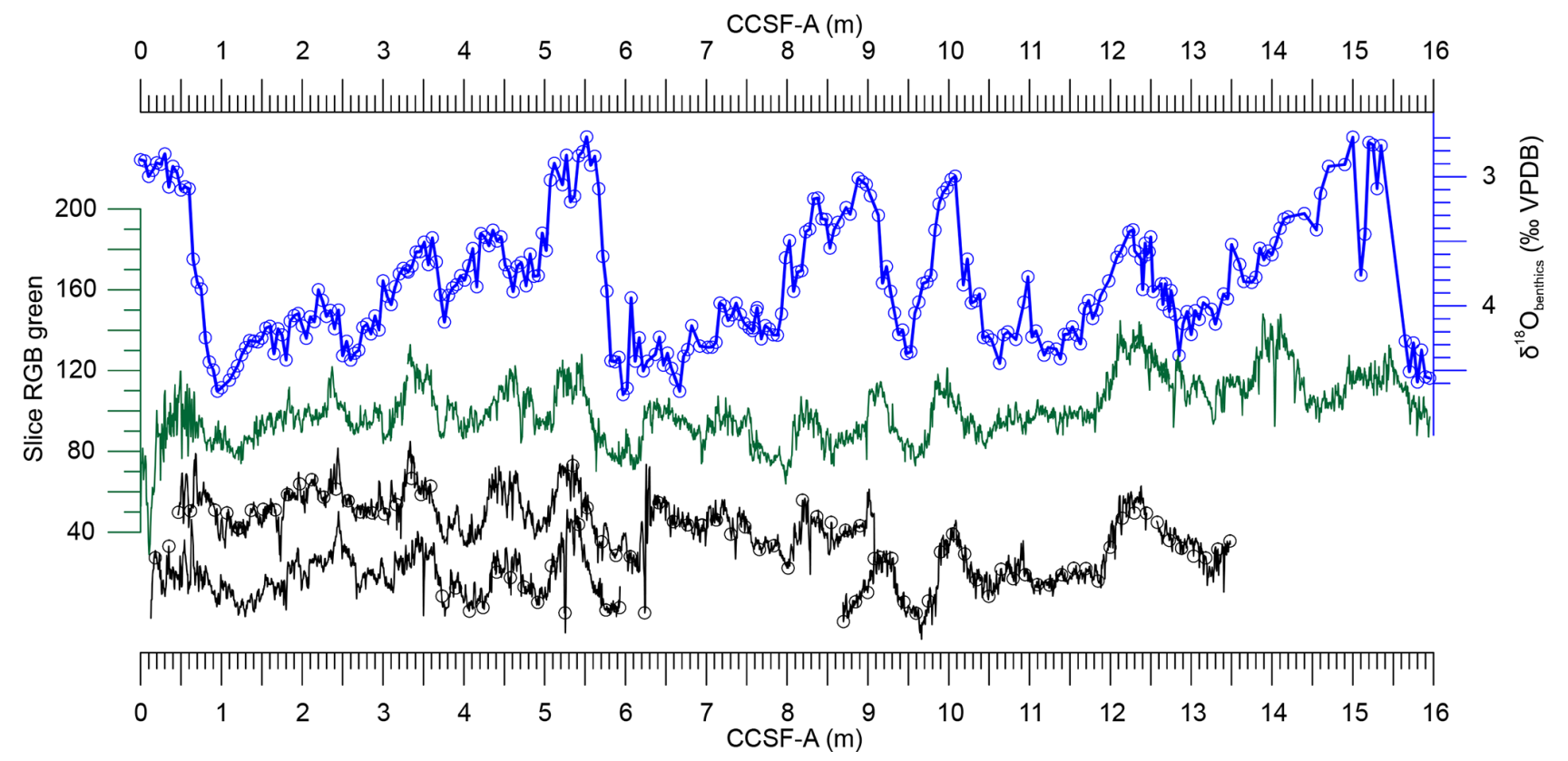

Figure 3. Correlation of upper cores of holes C, B, G and H of IODP Site U1479 (black) with the splice (green) using the green channel of the color scan (Hall et al., 2017, and shipboard data). Black curves are offset vertically for clarity. Positions of the pollen samples are denoted with black circles. On top the stable oxygen isotopes of Planulina wuellerstorfi are in blue (samples are denoted with blue circles). VPDB, Vienna PeeDee Belemnite. For more detail see Fig. S1 in the Supplement.

\subsection{Sample preparation}

Sample volume was measured using water displacement. Pollen samples were decalcified with cold $\mathrm{HCl}$ (ca. 10\%) and then treated with HF (ca. $40 \%$ ) for $2 \mathrm{~d}$. Concentrated $\mathrm{HCl}$ (ca. 37\%) was added to keep fluor-complexes in solution. Samples were sieved over a $7 \mu \mathrm{m}$ nylon screen while ultrasonically disaggregating organic matter. The residuals were stored in water, mounted in glycerol and examined under a light microscope (magnification 400 and $1000 \times$ ) for pollen, spores and micro-charcoal. Two Lycopodium spore tablets (batch no. 177745 containing $18584 \pm 829$ spores per tablet) were added during the decalcification step.

Pollen grains were identified using the African pollen reference collection of the Department of Palynology and Climate Dynamics of the University of Göttingen, the photo collection of the Department of Environmental and Geographical Science of the University of Cape Town, the African Pollen Database (http://apd.sedoo.fr/pollen/ interface/indexPollen.html, last access: 2 March 2021), and literature (Bonnefille and Riollet, 1980; Scott, 1982; Schüler and Hemp, 2016). Black opaque angular particles were counted as micro-charcoal.

\subsection{Statistical methods}

Percentages were calculated based on the sum of pollen and spores (ranging between 141 and 360). Pollen concentration was determined based on the Lycopodium spore counts and accumulation rates by multiplying the concentration with the sedimentation rate. The $95 \%$ confidence intervals of percentages were calculated following Maher (1972) and those of concentration values after Maher (1981). Pollen zones were determined using stratigraphically constrained cluster analysis (unweighted pair-group average and correlation similarity index) from the PAST package (Hammer et al., 2001), which is shown in Supplement Fig. S5.

The latitudinal insolation gradient (LIG) during Southern Hemisphere (SH) summer and winter was calculated using the insolation data of La04 (Laskar et al., 2004). SH summer LIG was calculated by subtracting the insolation at $30^{\circ} \mathrm{S}$ from that at $60^{\circ} \mathrm{S}$ on 21 December $\left(270^{\circ}\right)$, and $\mathrm{SH}$ winter LIG was calculated by subtracting the insolation at $30^{\circ} \mathrm{S}$ from that at $60^{\circ} \mathrm{S}$ on 21 June $\left(90^{\circ}\right)$.

We conducted pairwise regression analysis for a selection of pollen percentages against possible forcing mechanisms. Correlations are carried out using the Prais-Winsten regression method (Hammer et al., 2001). Significance of the correlations was determined after application of a Bonferroni correction; in this case we used a critical $p$ value of 0.05 divided by 55 (0.0009), indicating significance ( $p$ values are given in Table S1 in the Supplement). The BreuschPagan test for heteroskedasticity, i.e., nonstationary variance of residuals, indicated that in most cases homoskedasticity could not be rejected. Exceptions in which homoskedasticity was rejected at the $5 \%$ level are Poaceae percentages vs. summer LIG, Podocarpaceae and Stoebe-Elytropappus type 


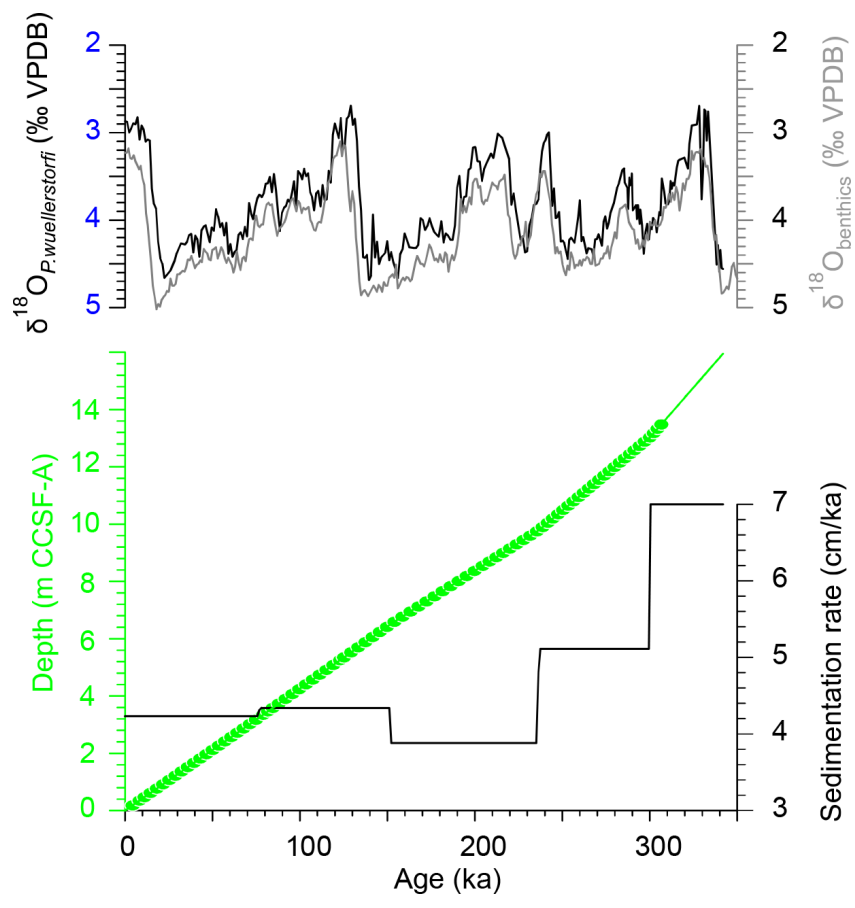

Figure 4. Age-depth model of the upper $14 \mathrm{~m}$ of IODP Site U1479 based on tuning of color channel data and resulting sedimentation rates. Green dots denote pollen samples. On top are the stable oxygen isotopes of benthic foraminifera of Site U1479 (black) and global stack LR04 (grey; Lisiecki and Raymo, 2005). VPDB, Vienna PeeDee Belemnite.

percentages vs. winter LIG, and Anthospermum and StoebeElytropappus type percentages vs. sea level. The residuals of all correlations failed the Durbin-Watson test for no positive autocorrelation (see also reference manual for PAST vs 4).

Also using PAST, spectral analysis was carried out with REDFIT (Schulz and Mudelsee, 2002), which does not need equidistantly spaced data. We employed a Hanning window with 2 times oversampling and two segments, resulting in a bandwidth of $0.00993 \mathrm{kyr}^{-1}$. To determine phase shifts between pollen data and insolation curves, we employed Blackman-Tukey cross-spectral analysis using ARAND software (Howell et al., 2006). Data were interpolated equidistantly and resampled every $3 \mathrm{kyr}$ between 3 and $306 \mathrm{ka}$. We applied 40 lags, resulting in a bandwidth of $0.01111 \mathrm{kyr}^{-1}$.

\section{Palynological results}

The main pollen types found are Restionaceae (7\%-27\%), Ericaceae (1\%-11\%) and Stoebe-Elytropappus type (2\%$11 \%)$. Other taxa from fynbos include Proteaceae, Rhamnaceae, Bruniaceae, Passerina and Cliffortia. Droughtadapted taxa are less abundant but consistently present and include Aizoaceae (up to $5 \%$ ), Ruschia type, Crassulaceae, Pentzia-Cotula type (up to 6\%), Amaranthaceae (up to
$8 \%$ ), Tribulus and Zaluzianskya type (compare Selago type of Scott, 1982). The most abundant type in some parts is Podocarpaceae pollen (up to $46 \%$ ), with other afrotemperate forest elements including pollen of Olea, Myrsine and Meliaceae-Sapotaceae. Fern spores of Anemiaceae and $\mathrm{Cy}$ athea type might also have their source in the forest. Elements from coastal thicket include Rhus type, Buxus, Celtis, Combretaceae, Ebenaceae, Euphorbiaceae pp., KiggelariaSpirostachys type, Antidesma, Morella and Dodonaea. Other important pollen types are Asteraceae pp. (6\%-22\%), Cyperaceae $(8 \%-27 \%)$, Poaceae $(1 \%-10 \%)$ and Anthospermum (up to $5 \%$ ). The percentage pollen diagram is divided into nine zones based on stratigraphically constrained cluster analysis (Fig. 5, Table 1, Supplement Figs. S2 and S5).

Total pollen concentration varies between 147 and 1168 grains $\mathrm{mL}^{-1}$. Concentration of most pollen types remains below 100 grains $\mathrm{mL}^{-1}$ except for Restionaceae (26-125 grains $\mathrm{mL}^{-1}$ ), Cyperaceae $\left(27-235\right.$ grains $\left.\mathrm{mL}^{-1}\right)$, Podocarpaceae (6-485 grains $\mathrm{mL}^{-1}$ ) and Asteraceae pp. (11-130 grains $\mathrm{mL}^{-1}$ ). With the exception of the Asteraceae, these are wind-pollinated plants. However, concentrations of wind-pollinated Poaceae pollen are relatively low (877 grains $\mathrm{mL}^{-1}$ ). Charcoal particle concentration varies between 2600 and 18000 particles $\mathrm{mL}^{-1}$ (Fig. 5). Long microcharcoal particles make up only a fraction of the total with ratios fluctuating between $3 \%$ and $18 \%$ except for two samples dated 3 and $7 \mathrm{ka}$, in which $21 \%$ and $25 \%$ of the microcharcoal particles are longish. Average sedimentation rates decrease from 7 to $5 \mathrm{~cm} \mathrm{kyr}^{-1}$ around $300 \mathrm{ka}$ and decline to ca. $4 \mathrm{~cm} \mathrm{kyr}^{-1}$ after $240 \mathrm{ka}$ (Fig. 4).

We performed spectral analysis on the accumulation rates (ARs) to avoid interdependence between the data as is the case with percentages. A log transformation $[\log (\mathrm{AR})]$ allows for the comparison of variables that spread across several orders of magnitude on a comprehensible scale. We analyzed the accumulation rates of total pollen and spores, micro-charcoal, Restionaceae, Asteraceae pp., Poaceae, Cyperaceae, Ericaceae, Podocarpaceae, StoebeElytropappus type, Anthospermum, Pentzia-Cotula type and fern spores (Tables 2 and 3). Accumulation rates are given in Supplement Fig. S3, and significant power maxima are given in Table 2. The spectral density (power) of the accumulation rates of these taxa exceeds the $90 \% X^{2}$ significance level in the precession band. Additional significant power in the obliquity band is found for Restionaceae, Poaceae and Stoebe-Elytropappus type. Cross-spectral analysis revealed these taxa to be negatively correlated with the Southern Hemisphere winter latitudinal insolation gradient ( $\mathrm{SH}$ winter LIG), lagging between 0 and $3 \mathrm{kyr}\left(0-42^{\circ}\right.$ phase shift). The highest coherency was found for the cross-spectrum of Podocarpaceae pollen accumulation rates with SH winter LIG multiplied by -1 (Table 3 ). 
Table 1. Pollen zone description.

\begin{tabular}{|c|c|c|c|c|}
\hline Zone & $N$ & Age (ka) & $\begin{array}{l}\text { Marine } \\
\text { stratigraphy* }\end{array}$ & Description based on pollen percentages \\
\hline VII & 13 & $307-274$ & late MIS 9 & $\begin{array}{l}\text { Podocarpaceae decline from } 29 \% \text { to } 10 \% \text { but have a maximum at the } \\
\text { end of the zone, Olea and Morella increase, Asteraceae pp. increase up } \\
\text { to } 16 \% \text {, Anthospermum increase up to } 3 \% \text {, Aizoaceae increase slightly } \\
(2 \%) \text {, Ericaceae maximum }(9 \%) \text { in the middle of the zone }\end{array}$ \\
\hline VI & 11 & $271-242$ & $\begin{array}{l}\text { MIS } 8, \text { T-IIIb, } \\
\text { early MIS } 7 \mathrm{e}\end{array}$ & $\begin{array}{l}\text { Podocarpaceae and thicket taxa are low with the exception of Morella, } \\
\text { Asteraceae pp. have a maximum }(20 \%) \text { in the beginning of the zone, } \\
\text { Ericaceae maxima up to } 11 \% \text {, Passerina maximum (3\%), increasing An- } \\
\text { thospermum up to } 4 \% \text {, Aizoaceae increase }(3 \%) \text {, increasing maxima of } \\
\text { Pentzia-Cotula type and Amaranthaceae up to } 6 \% \text { and } 8 \% \text {, respectively, } \\
\text { Zaluzianskya type maximum }(2 \%)\end{array}$ \\
\hline $\mathrm{V}$ & 4 & $239-228$ & $\begin{array}{l}\text { end of MIS 7e, } \\
\text { MIS } 7 \mathrm{~d}\end{array}$ & $\begin{array}{l}\text { Podocarpaceae maximum ( } 36 \%) \text {, small maximum of Olea }(2 \%) \text {, } \\
\text { decline of Anthospermum to } 1 \% \text {, Pentzia-Cotula type decline to } 2 \%\end{array}$ \\
\hline $\mathrm{IVb}$ & 23 & $224-142$ & $\begin{array}{l}\text { T-IIIa, MIS } 7 \mathrm{a}-\mathrm{c} \text {, } \\
\text { most of MIS } 6\end{array}$ & $\begin{array}{l}\text { Podocarpaceae vary between } 3 \% \text { and } 22 \% \text {, other forest and thicket taxa } \\
\text { occur mainly in the early part of the zone with the exception of Morella, } \\
\text { Restionaceae maximum of } 24 \% \text { at the beginning, Asteraceae pp. increase } \\
\text { up to } 22 \% \text {, Ericaceae relatively high (mean } 6 \% \text { ), Cliffortia increases and } \\
\text { Passerina reaches over } 2 \% \text {, Stoebe-Elytropappus type increases to max- } \\
\text { imum of } 11 \% \text {, Proteaceae decline, Amaranthaceae maxima up to } 6 \% \\
\text { early in the zone, Cyperaceae maximum }(27 \% \text { ) }\end{array}$ \\
\hline IVa & 3 & $139-135$ & end of MIS 6 & $\begin{array}{l}\text { Podocarpaceae maximum ( } 26 \%) \text {, Anthospermum maximum }(5 \%) \text {, short } \\
\text { Zaluzianskya type maximum, decline of Ericaceae }\end{array}$ \\
\hline
\end{tabular}

IIIb 4 133-125 T-II, early MIS 5e Podocarpaceae minimum of 2\%, Kiggelaria-Spyrostachys type maxi-
mum $(1 \%)$, most thicket elements occur, Poaceae maximum of $9 \%$, Restionaceae increase up to $22 \%$, Aizoaceae pp. maximum (5\%), Amaranthaceae maximum (4\%), Euphorbia maximum (2\%)

\begin{tabular}{|c|c|c|c|c|}
\hline IIIa & 17 & $123-64$ & $\begin{array}{l}\text { MIS } 5 \text { from the mid- } \\
\text { dle of MIS } 5 \text { e, early } \\
\text { MIS } 4\end{array}$ & $\begin{array}{l}\text { Podocarpaceae maxima }>40 \% \text { (mean } 29 \% \text { ), other forest and thicket el- } \\
\text { ements present but low, Restionaceae vary between } 7 \% \text { and } 20 \% \text {, most } \\
\text { fynbos and drought-adapted taxa low, Pentzia-Cotula type and Amaran- } \\
\text { thaceae decline from } 3 \% \text { at the beginning to } 0 \% \text { and } 1 \% \text { at } 88 \mathrm{ka} \text {, re- } \\
\text { spectively, Olea maximum at the end of the zone }\end{array}$ \\
\hline II & 11 & $61-25$ & $\begin{array}{l}\text { late MIS } 4 \text { to late } \\
\text { MIS } 2\end{array}$ & $\begin{array}{l}\text { Asteraceae pp. increase up to } 21 \% \text {, Ericaceae increase }(3 \%-9 \%) \text {, Passe- } \\
\text { rina increase up to } 2 \% \text {, Stoebe-Elytropappus type slightly increases } \\
(5 \%-9 \%)\end{array}$ \\
\hline I & 5 & $22-4$ & $\begin{array}{l}\text { late MIS 2, T-I, } \\
\text { MIS } 1\end{array}$ & $\begin{array}{l}\text { Podocarpaceae minimum ( } 2 \%) \text {, Restionaceae maximum ( } 27 \%) \text {, early in } \\
\text { the zone Pentzia-Cotula type }(6 \%) \text { and Anthospermum ( } 4 \%) \text { maxima, } \\
\text { Amaranthaceae ( } 6 \% \text { ) and Aizoaceae pp. }(5 \%) \text { maxima late in the zone, } \\
\text { forest elements such as Combretaceae and Kiggelaria-Spyrostachys type } \\
\text { increase }\end{array}$ \\
\hline
\end{tabular}

* MIS, marine isotope stage; $\mathrm{T}$, termination.

\section{Discussion}

\subsection{Source area and pollen transport}

The floral composition of the palynological assemblage of Site U1479 indicates that it records the biomes of South Africa, in particular that of the GCFR, although limited pollen transport from the east coast cannot be excluded
(Fig. 5, Supplement Fig. S2). The fynbos biome is represented by pollen from Restionaceae, Ericaceae, Proteaceae, Rhamnaceae, Bruniaceae, Passerina and Cliffortia. Pollen of Stoebe-Elytropappus type (here probably from Elytropappus, the renosterbos), Anthospermum and Asteraceae pp. may also be associated with the GCFR. Drought-adapted plants from families such as Aizoaceae, Crassulaceae, Scrophulariaceae (Zaluzianskya type), Euphorbia and certain 
Asteraceae (Pentzia-Cotula type) can be found in the succulent Karoo and the Nama Karoo. Afrotemperate forest is represented by Podocarpaceae, Olea and Myrsine, and thicket is indicated by the presence of pollen of Olea, Dodonaea, Morella, Kiggelaria-Spirostachys type (here probably from Kiggelaria), Ebenaceae, Combretaceae, Celtis and Rhus. Along the south coast, the same pollen taxa have been found at Still Bay (Quick et al., 2015) and/or at Vankervelsvlei (Quick et al., 2016). With exception of Podocarpaceae, the floristic composition also resembles records from the Cederberg Mountains near the border between mountainous fynbos and succulent Karoo (Scott and Woodborne, 2007a, b; Meadows et al., 2010; Quick et al., 2011).

The sediments of marine Site U1479 are thus rich in pollen and spores from southernmost Africa. This is remarkable because at present no big rivers discharge in the vicinity of the core location, and the general wind direction of the southern westerlies is landwards. Moreover, the site lies outside the influence of the SE trade winds. However, numerous smaller rivers drain the south coast of South Africa, which bring pollen and spores to the ocean. Further westward transport could derive from the Agulhas Current, which also transports clays into the Cape Basin (Petschick et al., 1996).

This situation was different during sea level lowstands, especially during the Last Glacial Maximum (LGM), when a wide network of rivers spread over the PAP (Cawthra et al., 2020). The Breede River, now discharging into the ocean near Cape Infanta west of Blombos Cave on the south coast, watered the western part of the PAP. During the LGM, the mouth of the Breede River was probably situated almost directly south of Cape Agulhas, some $250 \mathrm{~km}$ east of Site U1479 (Cawthra et al., 2020). Thus, during sea level lowstands the dominant source area of pollen and spores might have shifted from the present south coast and adjacent inland to the western part of the PAP.

\subsection{Vegetation development}

For the past $300 \mathrm{kyr}$, three terminations (i.e., rapid onset of interglacial conditions) have been recognized (Cheng et al., 2009): T-I at the beginning of MIS 1 (17-11 ka), T-II at the beginning of MIS 5 (ca. $130 \mathrm{ka}$ ) and T-IIIb at the beginning of MIS 7 (ca. $244 \mathrm{ka}$ ). Additionally, another termination (TIIIa) is placed at the beginning of MIS 7c (ca. $218 \mathrm{ka}$ ) as implied by the recognition of MIS 7c as a full interglacial (Past Interglacials Working Group of PAGES, 2016). Our data indicate a change in vegetation from ericaceous-rich fynbos with abundant Asteraceae during the glacial stages MIS 8, MIS 6 and MIS 2-4 via subsequently increased percentages of Anthospermum, Aizoaceae and Kiggelaria-Spirostachys type pollen during the terminations to more forest with Olea and Podocarpaceae during the interstadial stages MIS 7d and MIS 5d-a (Fig. 5). The representation of forest remained low during the Holocene.
During the last glacial-interglacial transition, a shift from ericaceous fynbos to a vegetation with more thicket species (Olea, Rhus, Euclea, Dodonaea, Myrsine) was found in records from the Cederberg Mountains (Scott and Woodborne, 2007a, b; Quick et al., 2011; Valsecchi et al., 2013). Around the Pakhuis Pass Site in the Cederberg Mountains the vegetation changed from abundant Proteaceae, Ericaceae, Stoebe-Elytropappus type, Passerina and Scrophulariaceae to increased Aizoaceae, Anthospermum, Dodonaea, Rhus, Euclea (Ebenaceae) and Olea (Scott and Woodborne, 2007b). Although the details differ, the marine sediments show a similar pollen sequence and might have recorded shifts in the regional abundance of fynbos, succulent vegetation, thicket and forest. However, it should be kept in mind that the marine sediments collect pollen and spores from a large area and that the subsequent maxima in the marine record would not represent a local vegetation succession.

Afrotemperate forest and littoral thicket elements are present in the pollen record of Vankervelsvlei in the wilderness embayment during the period from MIS 5c to MIS 3 (Quick et al., 2016), although percentages of Podocarpaceae pollen already declined around $80 \mathrm{ka}$. This record indicates a shift from ericaceous fynbos and renosterveld vegetation during the glacial period to asteraceous fynbos with few ticket and forest elements during the Holocene. The record of $\mathrm{Ri}-$ etvlei in the Still Bay area further to the west (Quick et al., 2015) exhibits high representation of Restionaceae but few other fynbos elements, limited trees and shrubs, and some succulents (Aizoaceae) during MIS 3. The Rietvlei record continues after $16 \mathrm{ka}$ with a reduced representation of fynbos and an increase in drought-resistant Amaranthaceae. fynbos and Proteaceae increase at the beginning of the Holocene (11 ka).

The subsequent changes in the vegetation around the terminations indicate influence of the glacial-interglacial cycle. Asteraceae, Ericaceae, Passerina and Anthospermum tend to be more abundant during glacial stages. Cooler temperatures during glacial stages might have favored Ericaceae (Quick et al., 2016). Podocarpaceae also seem to increase during cooler stages with possibly greater moisture availability, although not during glacial maxima. Low atmospheric $\mathrm{CO}_{2}$ during MIS 8, 6 and 2 might have hampered the growth of afrotemperate forests (Bereiter et al., 2015; Dupont et al., 2019). Probably more important is the exposure of the PAP south of the present coast during glacial stages. Especially when sea level sank below $-100 \mathrm{~m}$ (Fig. 1), a large area was exposed for colonization and growth of thicket, woodland on the floodplain, renosterveld and fynbos (Cowling et al., 2020). This is suggested by pollen percentages of the Asteraceae pp. $(r=0.34, p<0.001)$ and Ericaceae $(r=0.58$, $p<0.001)$ significantly correlating with modeled global sea level (Bintanja et al., 2005) (Fig. 6, Table 2). Rapid sea level rise during terminations would have swamped the vegetation on the Agulhas Bank and eroded the soils, which offers an alternative explanation for the subsequent pollen maxima 


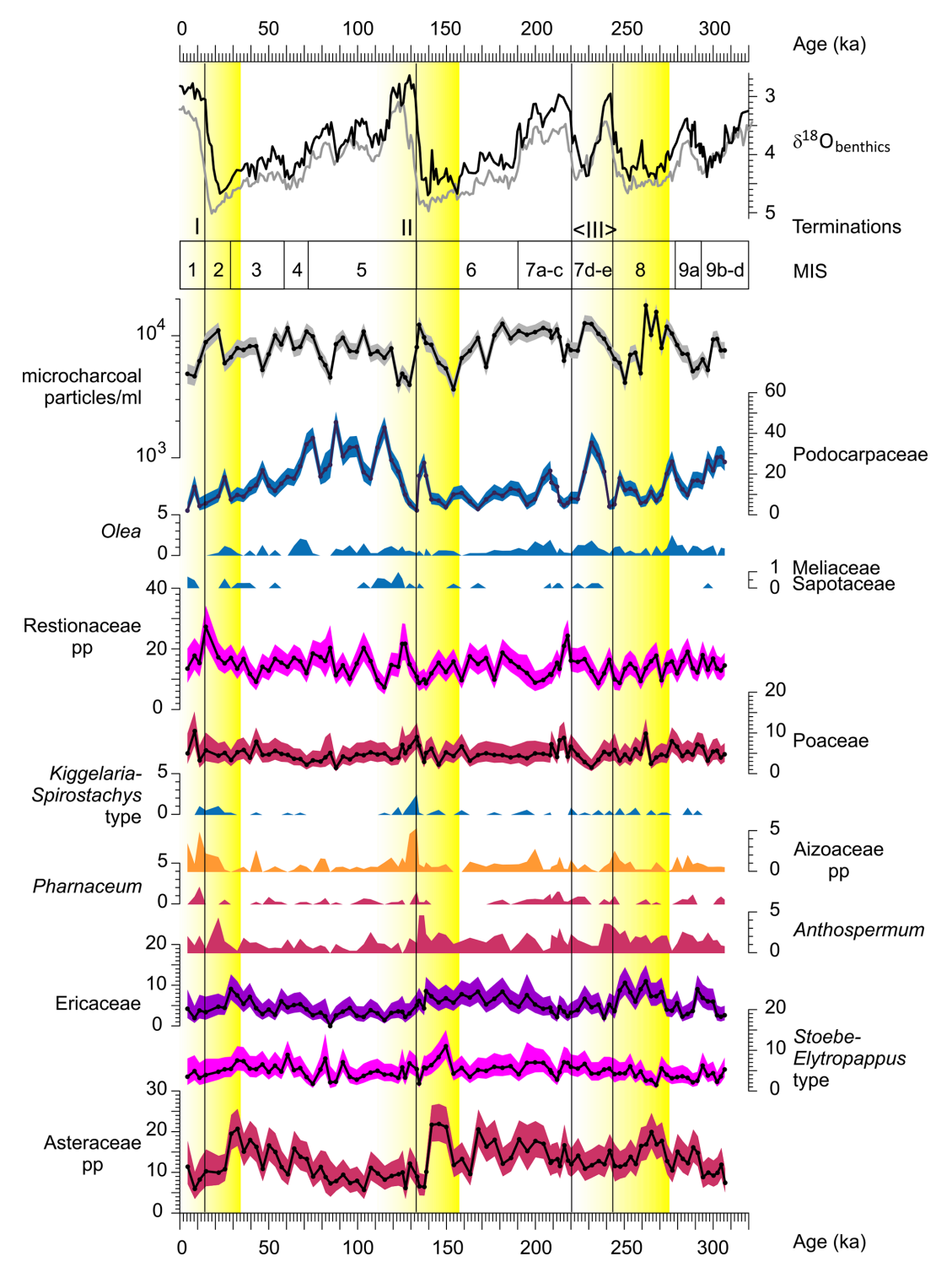

Figure 5. Percentages of selected pollen taxa with $95 \%$ confidence intervals and micro-charcoal particle concentration per milliliter. On top are the stable oxygen isotopes of benthic foraminifera in per mil VPDB (Vienna PeeDee Belemnite) of Site U1479 (black) and global stack LR04 (grey; Lisiecki and Raymo, 2005) as well as marine isotope stage (MIS). Vertical black lines denote Termination I (beginning of MIS 1), Termination II (beginning of MIS 5) and the double Termination III (MIS 7). Yellow color gradients denote the sequence of taxa described in the text.

of Anthospermum, Aizoaceae and Kiggelaria-Spirostachys type during Termination II (Fig. 5).

The modeled LGM vegetation on the PAP does not include forest (Cowling et al., 2020), perhaps because the climate and relatively flat geomorphology of the plain would favor rapid and expansive fires (Kraaij et al., 2020), precluding the growth of extensive forest on the plain. The low Podocarpaceae pollen percentages for the LGM corroborate this. However, we find a substantial increase in the representation of Podocarpaceae during MIS 7d and MIS 5 after the last interglacial maximum (MIS 5e) when sea level was around $40 \mathrm{~m}$ lower than at present. Also, Esper et al. (2004) found substantial amounts of bisaccate pollen (presumably from Podocarpaceae) corresponding to our Podocarpaceae maxima of MIS 5 in core GeoB3603-2 retrieved ca. $15 \mathrm{~km}$ east of Site U1479. This indicates that the PAP might not always have been as open, as suggested by the LGM reconstruction. It is also possible that during phases of increased summer rain (see next section), Podocarpaceae extended in the Cape Fold Belt Mountains and the pollen was transported by rivers, in particular the Breede River. Wood charcoal assemblages from Elands Bay Cave prior to $20 \mathrm{ka}$ give evidence for several species characteristic for afrotemperate for- 
Table 2. The $r$ values for linear correlations between concentration per milliliter of micro-charcoal particles with concentration values of selected pollen taxa (first column), between pollen percentages and foraminiferal stable oxygen isotopes (fifth column), and between pollen percentages and different possible forcing mechanisms such as the Southern Hemisphere summer latitudinal insolation gradient (LIG) (second column), the Southern Hemisphere winter LIG (third column) and sea level (fourth column; Bintanja et al., 2005). Correlations were calculated using pairwise regression analysis on equidistantly interpolated values resampled every $3 \mathrm{kyr}$ between 5 and $305 \mathrm{ka}$ (except column 1). We applied a Bonferroni correction, and $r$ values corresponding to a critical $p$ value $<0.0009(0.05 / 55)$ are denoted in bold. Column 6 indicates the periodicities in which the power of the accumulation rates of selected pollen taxa exceeds the $90 \% X^{2}$ level (REDFIT spectral analysis).

\begin{tabular}{|c|c|c|c|c|c|c|}
\hline \multirow[b]{2}{*}{ Taxon } & \multicolumn{5}{|c|}{$r$ linear correlation } & \multirow{2}{*}{$\begin{array}{r}\log (\mathrm{AR}) \text { power } \\
>90 \% X^{2} \\
\text { Periodicity } \\
\text { precession } \\
\text { band }\end{array}$} \\
\hline & $\begin{array}{l}\text { Conc. vs. } \\
\text { micro- } \\
\text { charcoal }\end{array}$ & $\begin{array}{r}\% \text { vs. } \\
\text { summer } \\
\text { LIG }\end{array}$ & $\begin{array}{r}\% \text { vs. } \\
\text { winter } \\
\text { LIG }\end{array}$ & $\begin{array}{r}\% \text { vs. } \\
\text { sea level }\end{array}$ & $\delta^{18} \mathrm{O}_{\text {benthics }}$ & \\
\hline Aizoaceae pp. & -0.01 & -0.29 & 0.15 & -0.21 & -0.52 & NV \\
\hline Pentzia-Cotula type & 0.27 & 0.00 & 0.03 & 0.10 & -0.05 & $19-25$ \\
\hline Amaranthaceae & 0.20 & -0.19 & 0.33 & -0.17 & -0.39 & $21-24$ \\
\hline Stoebe-Elytropappus type & 0.20 & 0.15 & 0.25 & 0.23 & 0.21 & *21-25 \\
\hline Anthospermum & 0.26 & -0.03 & 0.13 & 0.27 & 0.10 & $22-25$ \\
\hline Asteraceae pp. & $* 0.42$ & 0.24 & 0.19 & $* 0.34$ & 0.34 & $20-25$ \\
\hline Ericaceae & $* \mathbf{0 . 4 0}$ & 0.09 & -0.01 & $*^{*} \mathbf{0 . 5 8}$ & 0.57 & $* 20-25$ \\
\hline Podocarpaceae & 0.21 & 0.19 & *-0.39 & -0.34 & -0.03 & *19-25 \\
\hline Restionaceae pp. & $* 0.44$ & -0.05 & 0.26 & 0.06 & -0.11 & $* 22$ \\
\hline Poaceae & 0.30 & *_0.37 & 0.14 & -0.06 & -0.27 & $19-24$ \\
\hline Cyperaceae & 0.31 & -0.34 & 0.08 & 0.22 & 0.15 & $19-24$ \\
\hline
\end{tabular}

* Curves shown in Figs. 6-8.

est, including Podocarpus elongates, which were probably growing along rivers and streams (Cowling et al., 1999).

\subsection{Open grasslands in the southwestern Cape?}

Pollen percentages for grasses are rather low (maximum of $10 \%$, mean $5 \%$ ), which is in line with glacial terrestrial pollen records of Cederberg Mountains and the south coast (Meadows and Sudgen, 1991; Scott and Woodborne, 2007a, b; Quick et al., 2011, 2015, 2016; Valsecchi et al., 2013). Grass pollen is also relatively scarce at Vankervelsvlei, and at Rietvlei grass pollen is only abundant during the early Holocene (Quick et al., 2015, 2016). Modern values from the Namaqualand mudbelt along the west coast of South Africa run from ca. $10 \%$ Poaceae pollen near Elands Bay adjacent to fynbos vegetation to ca. $40 \%$ in front of the Orange River, which drains the grass-rich landscapes of the South African interior (Zhao et al., 2016). Thus, the low Poaceae pollen percentages at Site U1479 are comparable to modern values derived from fynbos and renosterveld and do not indicate extensive grasslands in the western part of the GCFR at any time during the past $300 \mathrm{kyr}$.

In contrast to the pollen record, the Pleistocene fossil record of large-bodied herbivores from the GCFR has long been interpreted as indicating an expansion of grasslands, especially during glacial phases (Klein, 1983). South coast sites dating from MIS 6 onwards (e.g., Blombos Cave, Die
Kelders Cave, Klasies River, Nelson Bay Cave, Pinnacle Point; for locations see Fig. 1) frequently include extinct or extralimital grazers (e.g., Klein, 1972, 1976, 1983; Klein and Cruz-Uribe, 2000; Henshilwood et al., 2001; Rector and Reed, 2010), with very high abundances of grazers often observed during the LGM and late glacial (Klein, 1972, 1978, 1983; Faith, 2013). Stable isotope evidence $\left(\delta^{13} \mathrm{C}\right)$ from ungulate grazers at Boomplaas Cave indicate consumption of primarily $\mathrm{C}_{3}$ grasses during the LGM (Sealy et al., 2016), as is also the case at Nelson Bay Cave (Sealy et al., 2020). Williams et al. (2020) measured stable isotopes on teeth of micromammals and macromammals from a hyena den found at Pinnacle Point dated to MIS 6 (penultimate glaciation). The micromammal $\delta^{13} \mathrm{C}$ indicates a $\mathrm{C}_{3}$ vegetation in the immediate surrounding of the den, while the macromammal teeth indicate more mixed $\mathrm{C}_{3}-\mathrm{C}_{4}$ grasslands for the surrounding plain.

To reconcile the fossil pollen records with the fossil bone records from the south coast, one could hypothesize that the climate displayed a strong east-west gradient along the Paleo-Agulhas Plain from winter rainfall in the west to increased summer rainfall in the east. This pattern is indicated by the downscaling of the LGM results of coupled global climate model simulations to the region (Engelbrecht et al., 2019). Mapping of the glacially exposed PAP places the grasslands mainly in the central and eastern part of the plain, with fynbos and renosterveld vegetation dominating 

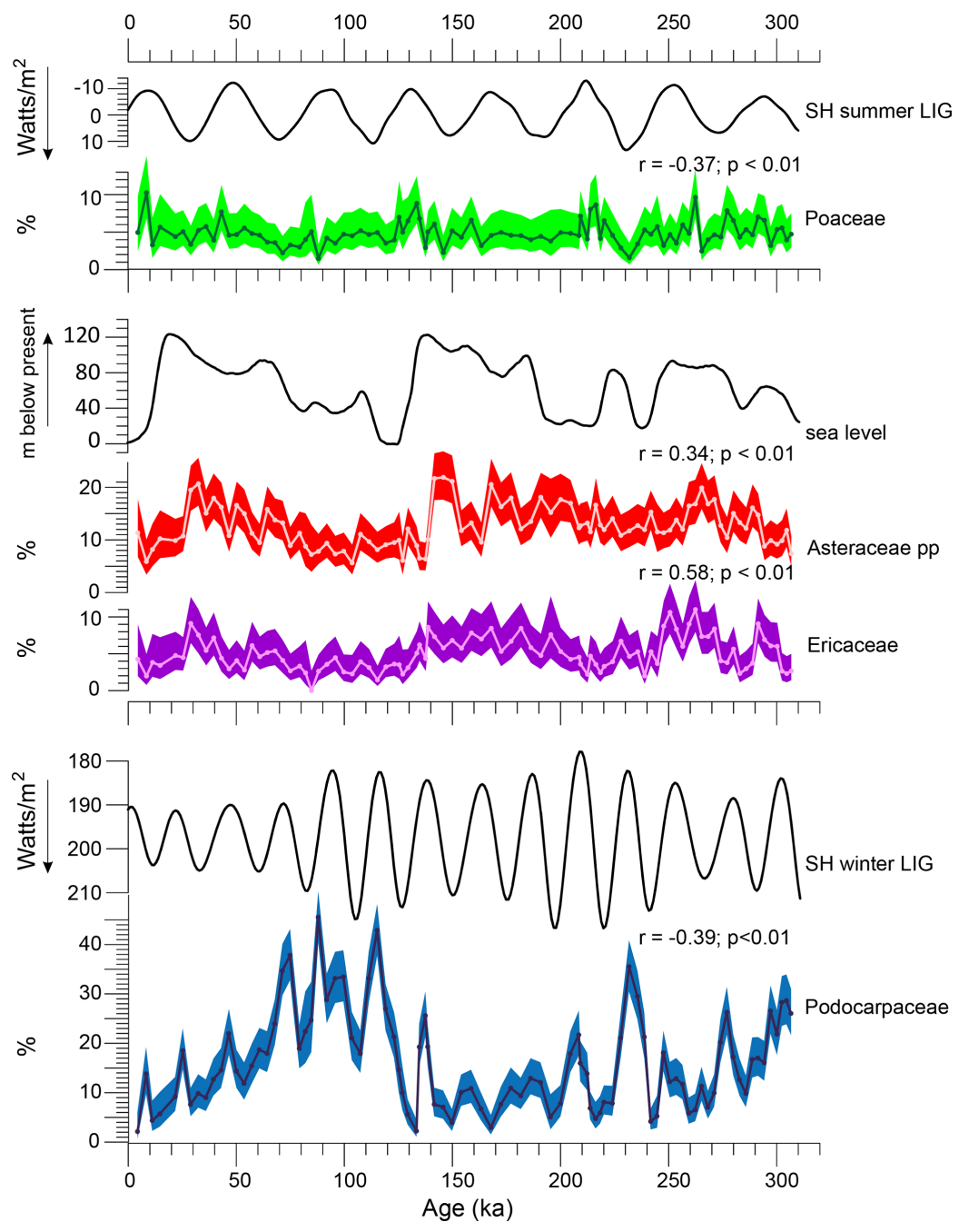

Figure 6. Comparison of pollen percentages of Poaceae with the Southern Hemisphere summer latitudinal insolation gradient (SH summer LIG), of Asteraceae pp. and Ericaceae with sea level (Bintanja et al., 2005), and of Podocarpaceae with the Southern Hemisphere winter latitudinal insolation gradient (SH winter LIG). Insolation gradients were calculated using the astronomical solution of La04 (Lascar et al., 2004). Note the reversed scales. Shading indicates $95 \%$ confidence intervals.

the western part during the LGM (Cowling et al., 2020; Marean et al., 2020). It is envisaged that the PAP would have harbored grazers migrating from the west in winter to the east in summer and back to make optimal use of grazing opportunities between winter rainfall and summer rainfall regions (Marean, 2010; Faith and Thompson, 2013; Copeland et al., 2016). However, a test of this proposed migration using isotopic measurements of serially drilled herbivore teeth from Pinnacle Point could not definitively corroborate a seasonal migration pattern (Hodgkins et al., 2020).

In this scenario, the pollen assemblages at Site U1479 would mainly register the vegetation of renosterveld, fynbos and riparian woodlands on the PAP. However, this concept is inconsistent with fossil evidence of micromammals and macromammals indicating that the latest Pleistocene witnessed an expansion of open grassland relative to modern times in the southwestern Cape as well (Avery, 1982; Klein and Cruz-Uribe, 1987, 2016). Glacial faunal assemblages document numerous grazers and open-country species (e.g., springbok, wildebeest, white rhino, quagga). For instance, Elands Bay Cave (Klein and Cruz-Uribe, 1987, 2016), Swartklip 1 (Klein, 1975), Hoedjiespunt 1 (Klein, 1983) and Die Kelders Cave (Klein and Cruz-Uribe, 2000) all indicate abundant grazing fauna feeding mainly on $\mathrm{C}_{3}$ grasses (Sealy et al., 2016, 2020). Also, the LGM pollen spectra from Elands Bay Cave show strongly increased grass pollen percentages (Parkington et al., 2000). Perhaps a grassy understory, such as those often associated with the renosterveld, were sufficient to support these grazers. Alternatively, the vegetation of the western portion of the PAP consisted more of a mixture between grassland, fynbos and renosterveld. However, the modern vegetation of the southwest- 
ern Cape does not support grazers, such as mountain zebra (Equus zebra), very well (Faith, 2012). The grass species composition in pre-Holocene renosterveld may have differed from the modern situation (and was possibly more palatable). Unfortunately, grass pollen cannot be determined to species level so we cannot assess the specific grasses available to these grazers. We could also speculate that grazing pressure might have subdued flowering and pollen production of the grasses or that reduced atmospheric $\mathrm{CO}_{2}$ enhanced grass quality (lower $\mathrm{C}: \mathrm{N}$ ratio) and supported greater grazer biomass (e.g., Owensby et al., 1996). On the other hand, the grasslands of the western portion of the PAP might be underrepresented in the pollen records because other plants in the vegetation, such as Restionaceae, produced more pollen. This may result in a pollen record that underestimates the extent of grasses in these ecosystems. A final possible explanation for the discrepancy between the pollen and bone records is that Pleistocene grazers may have browsed more than their Holocene counterparts (e.g., Stynder, 2009).

\subsection{Vegetation associated with fire}

Elevated micro-charcoal concentrations seem to be associated with fynbos vegetation (Fig. 7, Table 2). Significant positive linear correlations $(p<0.001)$ were found between micro-charcoal and pollen concentrations of Asteraceae pp. $(r=0.42)$, Restionaceae $(r=0.44)$ and Ericaceae ( $r=0.40$ ), but not with Stoebe-Elytropappus type. A weak correlation was found between concentrations of microcharcoal and Pentzia-Cotula type $(r=0.27)$ and between micro-charcoal and Podocarpaceae $(r=0.21)$, while no correlation was found between the micro-charcoal record and Amaranthaceae or Aizoaceae pollen concentrations. The micro-charcoal record indicates that, as expected, fires were more frequent in asteraceous and ericaceous fynbos vegetation but maybe less frequent in the renosterveld (Mucina and Rutherford, 2006). Minimum micro-charcoal concentrations occurred during the interglacials MIS 7c, MIS 5e and MIS 1, and they were similarly reduced during MIS 8 and MIS 4. Quick et al. (2016) found lower charcoal concentrations corresponding to a better representation of thicket species at Vankervelsvlei associated with decreased seasonality.

\subsection{Orbital forcing}

Precessional forcing is thought to be an important driver of South African climates. Previously, Partridge et al. (1997) proposed precessional forcing of rainfall in eastern South Africa. More recently, studies of independently dated marine sediments have confirmed the importance of precessional forcing, whereby increased precipitation occurred during maximum precession; a micro-charcoal and pollen record from the eastern South Atlantic indicated precessional forcing on the seasonality and amount of rainfall in the summer rainfall region of southern Africa (Daniau et al., 2013;

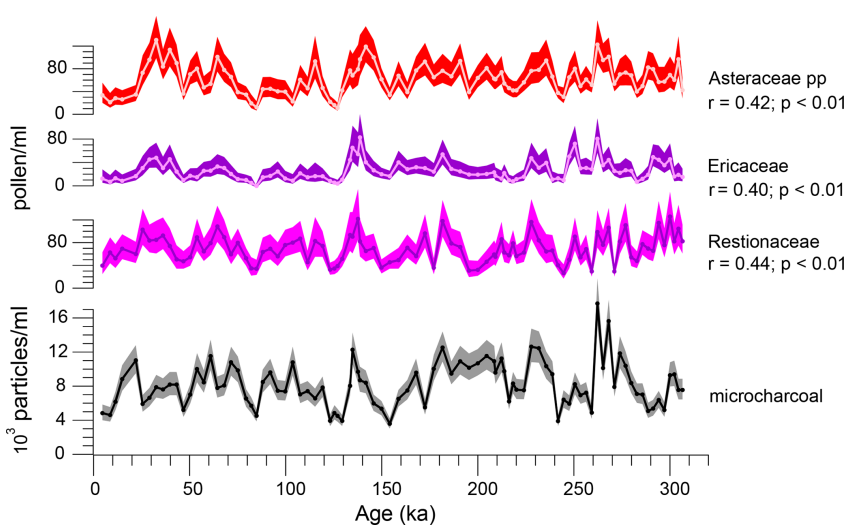

Figure 7. Comparison of micro-charcoal particle concentration with pollen concentrations of Asteraceae pp., Ericaceae and Restionaceae. Shading indicates $95 \%$ confidence intervals.

Urrego et al., 2015), while records from the western Indian Ocean revealed precession-driven discharge of southeast African rivers, such as the Limpopo and Tugela rivers (Simon et al., 2015; Caley et al., 2018). The influence of SST on the precipitation in the region does not seem to have an effect on precessional rhythms as the SST of the Agulhas waters in the western Indian Ocean does not show a precessional rhythm (Caley et al., 2011, 2018). Along the west coast of South Africa, Esper et al. (2004) found strong precession variability in the dinoflagellate cyst record of core GeoB3603-2 (located ca. $15 \mathrm{~km}$ east of Site U1479), indicating that stratified oligotrophic waters prevailed when precession was weak.

Sensitivity modeling using maximum and minimum precession showed that austral summer precipitation in southeast Africa is higher when precession is at maximum. Maximum precession results in maximum austral summer insolation (Bosmans et al., 2015; Simon et al., 2015), increasing the extension of the summer rainfall zone (SRZ) and probably the year-round rainfall zone (YRZ). The model experiment indicates that maximum precession induces weakening of the Southern Hemisphere westerlies (Simon et al., 2015). The SH westerlies might be affected by the latitudinal temperature gradient during SH winter, which is strongly related to the SH winter LIG (i.e., the difference in insolation between high and middle southern latitudes during austral winter). This gradient is minimal during maximum precession and would explain the weakening of the $\mathrm{SH}$ westerlies during maximum precession. Conversely, strong SH winter LIG during precession minima could induce strong westerlies, resulting in more precipitation, intensified seasonality and an extension of the winter rainfall zone (WRZ) at the cost of the YRZ along the south coast. For that reason we compare our results with the $\mathrm{SH}$ winter LIG.

In line with the mentioned inferences from marine sediments (Daniau et al., 2013; Urrego et al., 2015; Simon et al., 2015; Caley et al., 2018), our spectral analysis results 
Table 3. Results of the Blackman-Tukey cross-spectrum analysis (3-306 ka, step $3 \mathrm{kyr}, 40$ lags, bandwidth $0.01111 \mathrm{kyr}^{-1}$ ) executed with ARAND software (Howell et al., 2006). Phase is given at the precession band for SH winter LIG multiplied by -1 against the log(AR) in $\mathrm{cm}^{2} \mathrm{kyr}^{-1}$ for fern spores, selected pollen taxa, total pollen and spores, and micro-charcoal. The $95 \%$ level of nonzero coherency is 0.84 (denoted in bold); the $80 \%$ level of nonzero coherency is 0.70 . These taxa exhibit a negative correlation with SH winter LIG, lagging by up to $2.6 \mathrm{kyr}$.

\begin{tabular}{lrrrr}
\hline & \multicolumn{4}{c}{ SH winter LIG) $\times(-1)$} \\
\cline { 2 - 5 } Taxon $\log (\mathrm{AR})$ & Coherency & Phase $\left(^{\circ}\right)$ & Error $\left(^{\circ}\right)$ & Lag $(\mathrm{kyr})$ \\
\hline Fern spores & $\mathbf{0 . 8 4}$ & $\mathbf{4 1}$ & $\mathbf{1 7}$ & $\mathbf{2 . 6}$ \\
Pentzia-Cotula type & 0.78 & 6 & 22 & 0.4 \\
Podocarpaceae & $\mathbf{0 . 9 9}$ & $\mathbf{2 3}$ & $\mathbf{3}$ & $\mathbf{1 . 5}$ \\
Stoebe-Elytropappus type & $\mathbf{0 . 9 5}$ & $\mathbf{4 2}$ & $\mathbf{1 0}$ & $\mathbf{2 . 6}$ \\
Ericaceae & $\mathbf{0 . 8 6}$ & $\mathbf{2 4}$ & $\mathbf{1 6}$ & $\mathbf{1 . 5}$ \\
Cyperaceae & $\mathbf{0 . 8 9}$ & $\mathbf{2 0}$ & $\mathbf{1 5}$ & $\mathbf{1 . 5}$ \\
Poaceae pp. & 0.76 & 34 & 23 & 2.2 \\
Asteraceae pp. & $\mathbf{0 . 8 7}$ & $\mathbf{1 1}$ & $\mathbf{1 5}$ & $\mathbf{0 . 7}$ \\
Restionaceae & $\mathbf{0 . 9 1}$ & $\mathbf{6}$ & $\mathbf{1 2}$ & $\mathbf{0 . 4}$ \\
Total pollen and spores & $\mathbf{0 . 9 5}$ & $\mathbf{2 4}$ & $\mathbf{9}$ & $\mathbf{1 . 6}$ \\
Micro-charcoal & $\mathbf{0 . 8 6}$ & $\mathbf{1 8}$ & $\mathbf{1 6}$ & $\mathbf{1 . 1}$ \\
\hline
\end{tabular}

also indicate a strong influence of precession (Tables 2 and 3; Fig. 8). The precession component in the pollen accumulation rates is not an artifact of the age model based on tuning of the color data as the age-model-derived sedimentation rates are rather constant. Moreover, spectral analysis of pollen percentages which are independent of changes in sedimentation also reveals precession variability (not shown, but see the correlation between Podocarpaceae pollen percentages and the SH winter LIG in Fig. 6). Cross-spectral analysis indicates a negative correlation between the $\mathrm{SH}$ winter LIG and the accumulation rates of fern spores and pollen of Pentzia-Cotula type, Podocarpaceae, Stoebe-Elytropappus type, Ericaceae, Cyperaceae, Poaceae pp., Asteraceae pp. and Restionaceae (Table 3). An increase in summer rain and decreased seasonality might have been favorable for the growth of Podocarpaceae, explaining the significant negative correlation $(r=-0.39)$ of Podocarpaceae percentage values with the SH winter LIG (Fig. 6, Table 2). Increased discharge of rivers in the YRZ during maximum precession could explain the precession variability in the accumulation rates of other taxa (Table 2).

Accumulation rates of Podocarpaceae pollen show the highest coherency with SH winter LIG, and the maximum in accumulation rates occurs $1.5 \pm 0.2 \mathrm{kyr}$ after the minimum of SH winter LIG (phase lag of $23^{\circ} \pm 3$ between precessional forcing and vegetation response; Table 3 ). Our results are in line with a transient simulation of monsoon climate over the past $280 \mathrm{kyr}$ focusing on precession variability (Kutzbach et al., 2008). This simulation indicated that the South African monsoon (in the SRZ) responded with a phase lag of slightly less than 1 month $\left(30^{\circ}\right)$ to maximum December insolation, which is very close to the response of Podocarpaceae pollen accumulation rates.
Apart from precession variability our results also indicate some influence of obliquity. Obliquity forcing could be explained by the latitudinal temperature gradient during summer (Davis and Brewer, 2009) that can be estimated by the SH summer LIG. Cyperaceae and Poaceae accumulation rates show power at obliquity periods, while Poaceae and Cyperaceae pollen percentages correlate negatively with SH summer LIG (Fig. 6, Table 2). Also, pollen accumulation rates of Restionaceae and Stoebe-Elytropappus type show significant power at the obliquity band. However, Ericaceae and other fynbos-related elements only show significant precession variability, hinting at a heterogeneous response of different vegetation types in the GCFR.

\subsection{Comparison with the Piacenzian record}

In a separate study, Zhao et al. (2020) described the late Pliocene (Piacenzian) vegetation development of southwestern Africa based on pollen, micro-charcoal and benthic foraminifera oxygen isotope records of the same IODP Site U1479. We compare the two periods: the period from 3337 to $2875 \mathrm{ka}$ including the mid-Piacenzian Warm Period (mPWP, 3264-3025 ka) with the period of this study (307$0 \mathrm{ka}$ ). The pollen assemblages of both periods show continuity in the floristic composition, although differences in the relative abundance are obvious (Fig. 9).

The most striking differences between the pollen assemblages are changes in the abundances of Podocarpaceae and Restionaceae (Fig. 9, Supplement Fig. S4). While during the Piacenzian, Podocarpaceae pollen percentages range between $1 \%$ and $15 \%$ with a median of $4.5 \%$, maximum values and variability are much higher during the past $300 \mathrm{kyr}$ ( $2 \%-46 \%$, median $14.4 \%$ ). Conversely, the percentages for Restionaceae are much higher in the Piacenzian (18\%-47\%, 

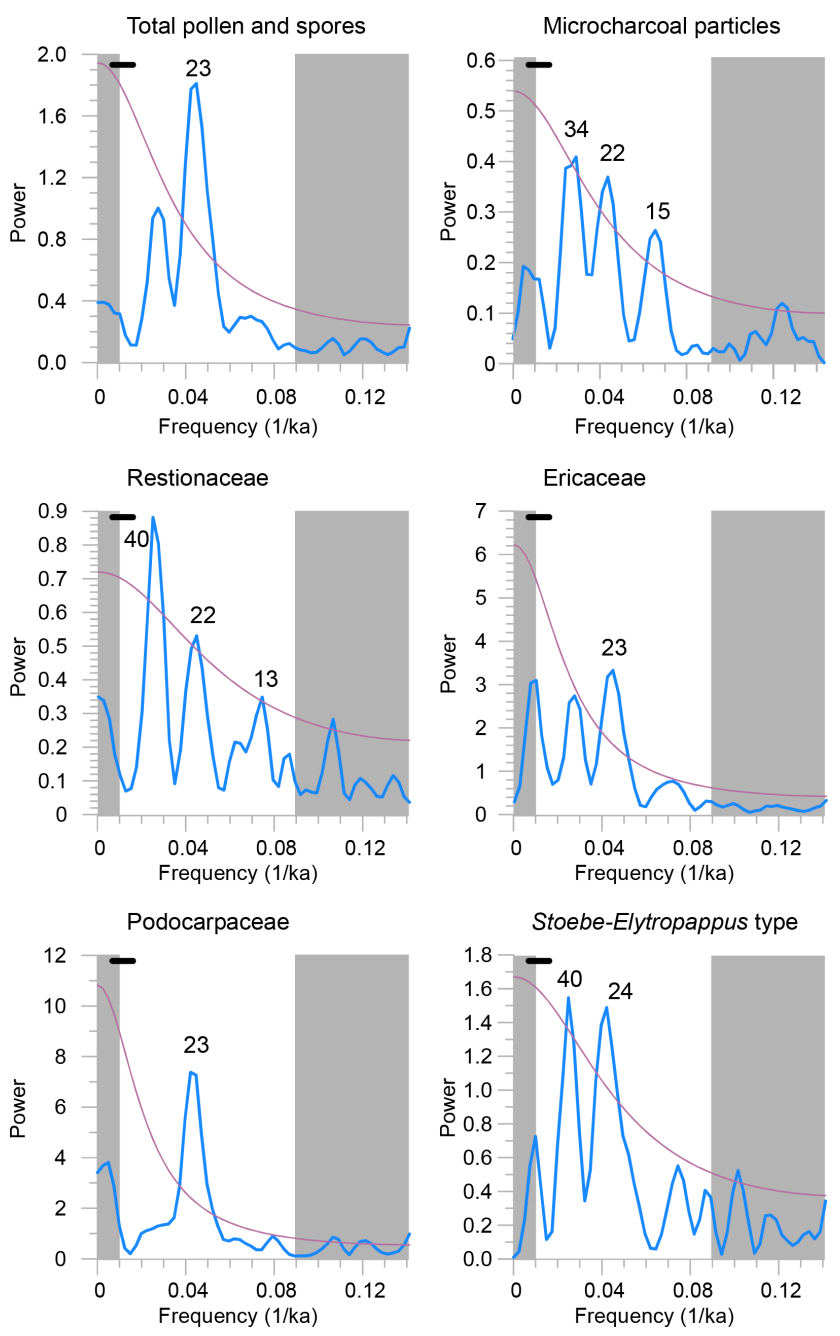

Figure 8. Spectral analysis of the logarithmically transformed accumulation rates of total pollen and spores, micro-charcoal particles, and pollen of Restionaceae, Ericaceae, Podocarpaceae and Stoebe-Elytropappus type using REDFIT (Schulz and Mudelsee, 2002; PAST, Hammer et al., 2001). Lilac lines denote the $90 \% X^{2}$ significance level. Bandwidth is indicated by the bars in the top left of each panel. Grey shading obscures the spurious results for frequencies that are either too high for the resolution or too low for the length of the record.

median $33.2 \%)$ than in the Pleistocene $(7 \%-27 \%$, median $14.6 \%)$. Other changes in the assemblages are less dramatic but still important. Aizoaceae pp. (excluding Ruschia type) pollen has prominent values during the Pleistocene but hardly occurs during the Piacenzian. Zaluzianskya type pollen occurs continuously in the Pleistocene, reaching maximum values of $2 \%$, but its regular appearance started only after $3060 \mathrm{ka}$ in the Pliocene record. On the other hand, Protea pollen is much more abundant during the Piacenzian. Finally, maximum values and variability for Anthospermum, Stoebe-Elytropappus type, Asteraceae and Ericaceae increased in the Pleistocene.
The decline in the representation of Restionaceae and the increase in Podocarpaceae after the Pliocene indicate shrinking of the WRZ and the area with fynbos. An increase in Aizoaceae and Zaluzianskya type suggests some expansion of the succulent Karoo. Generally cooler and possibly drier conditions of the Pleistocene could have induced these shifts in vegetation. Extension or westward shift of the YRZ could have allowed Podocarpaceae to spread into the southwestern Cape, where it nowadays occupies pockets in the Cape Fold Belt Mountains (Mucina and Geldenhuys, 2006).

Zhao et al. (2020) interpreted the Piacenzian pollen record as the result of climate change in relation to SST and the SH winter LIG. The combination of a strong latitudinal insolation gradient inducing strong southern westerlies and warm SST would have increased precipitation in the WRZ during the Piacenzian. Conversely, a weak insolation gradient and weak westerlies in combination with cool SST would have decreased the winter precipitation and reduced the extension of the WRZ along the south coast. These climatic conditions would have shifted the composition of the fynbos vegetation to more Ericaceae-rich and increased the afrotemperate forest (Podocarpaceae) in the YRZ. These mechanisms were probably still effective in the Pleistocene and suggest that the WRZ was reduced during MIS 4 and the cooler periods of MIS 5. Increased glacial-interglacial variability, decreased SST (especially in the upwelling regions) and low atmospheric $\mathrm{CO}_{2}$ during glacial periods further affected the vegetation (Dupont et al., 2019). Restionaceae became less abundant and Podocarpaceae forest extended during specific periods such as MIS 5d-a.

Not only did the variability and relative abundance of pollen taxa change, but the rhythm in the variability also differs between the Piacenzian and Pleistocene. Spectral analysis of percentage, concentration and accumulation values of the most important pollen taxa showed precessional (24$18 \mathrm{kyr}$ ) variability but no power in the obliquity band (40$42 \mathrm{kyr}$ ) during the Piacenzian (Zhao et al., 2020), whereas the Pleistocene record shows significant power at the obliquity period in the pollen accumulation rates of Restionaceae, Cyperaceae and Poaceae.

The appearance of the obliquity rhythm in the Pleistocene pollen record might be an effect of the much larger climate change between glacial and interglacial periods, but it could also be the result of vegetation on the PAP during periods of low sea level during the Pleistocene. During these low sea level periods, especially when global sea level dropped below $-100 \mathrm{~m}$, exposed regions became available for Asteraceaerich vegetation such as renosterveld, thicket and woodland on the floodplains. Also, drought-adapted pioneers might have found suitable habitats on the PAP during Pleistocene glaciations. The dramatic environmental changes that must have accompanied the flooding of the PAP during terminations would have induced both erosion and changes in the vegetation reflected in the pollen record. 


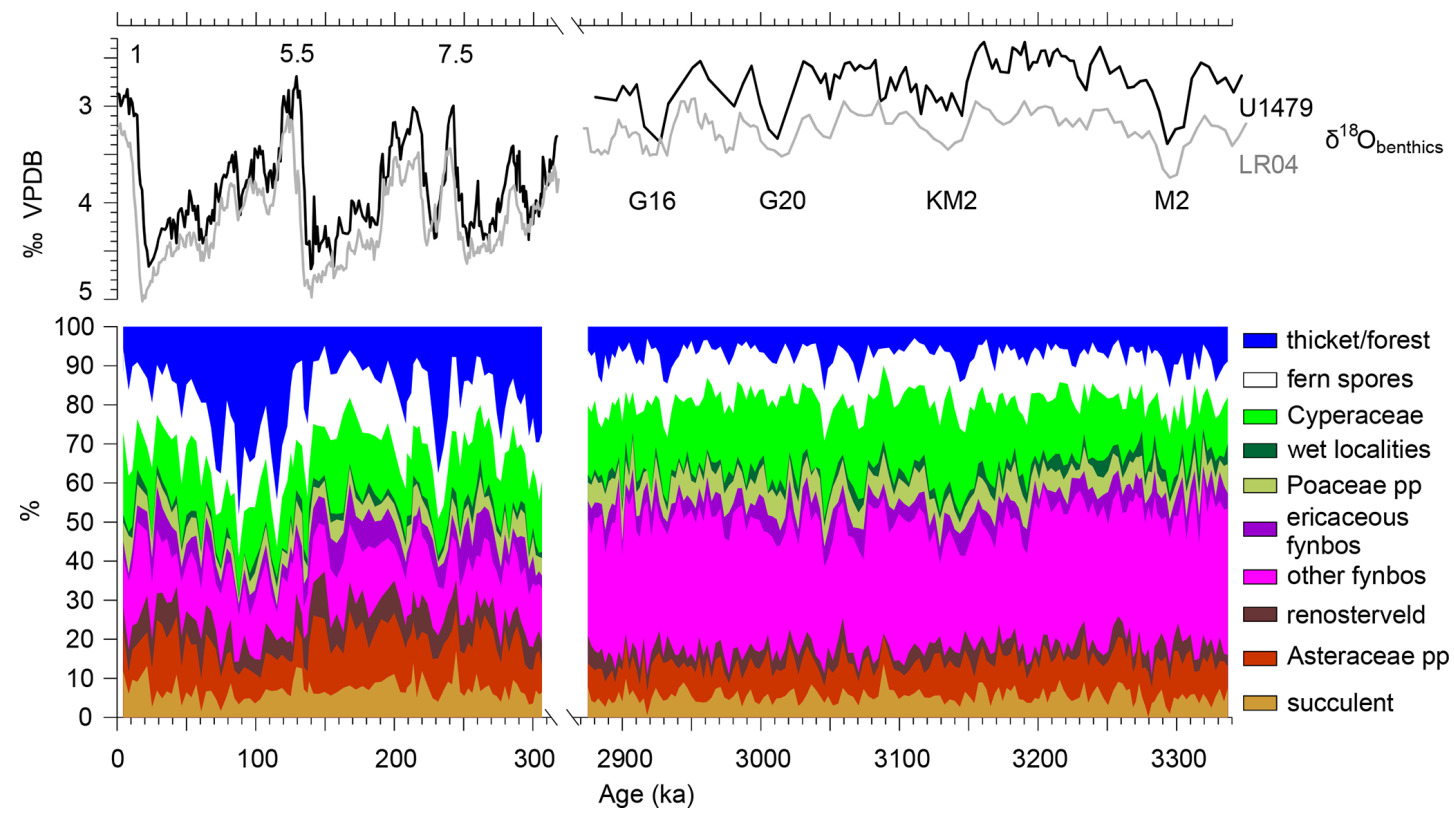

Figure 9. Summary diagram of the Pleistocene (left) and the Pliocene (right) pollen record of Site U1479. On top are the stable oxygen isotopes of benthic foraminifera in per mill VPDB (Vienna PeeDee Belemnite) of Site U1479 (black) and global stack LR04 (grey; Lisiecki and Raymo, 2005) as well as marine isotope stage (MIS). Note the larger fluctuations in the Pleistocene compared to the Pliocene, the strong increase in pollen from thicket and forest (mainly Podocarpaceae), the increase in Asteraceae pp., a slight increase in succulent elements, and the decline in other fynbos pollen types (mainly Restionaceae). Pollen groups are listed in Table 4.

Table 4. Groups of pollen taxa in Fig. 9. Grouping follows Quick et al. (2015, 2016).

\begin{tabular}{|c|c|}
\hline Ericaceous fynbos & Ericaceae, Thymelaeaceae (incl. Passerina) \\
\hline Other fynbos & Bruniaceae, Proteaceae, Restionaceae, Rhamnaceae \\
\hline Renosterveld & Stoebe-Elytropappus type, Cliffortia, Anthospermum \\
\hline $\begin{array}{l}\text { Succulent and drought- } \\
\text { adapted }\end{array}$ & $\begin{array}{l}\text { Aizoaceae, Amaranthaceae, Crassulaceae, Euphor- } \\
\text { bia, Zaluzianskya type, Tribulus, Pentzia-Cotula type }\end{array}$ \\
\hline Thicket-forest & $\begin{array}{l}\text { Rhus type, Dracaena, Buxus, Celastraceae, Combre- } \\
\text { taceae, Ebenaceae, Euphorbiaceae pp., Kiggelaria- } \\
\text { Spirostachys type, Morella, Olea, Podocarpaceae, } \\
\text { Myrsine, Dodonaea viscosa, Sapotaceae, Celtis, Ilex, } \\
\text { Pycnanthus, Syzygium type, Anemiaceae, Polypodi- } \\
\text { aceae, Pteris-Cyathea type }\end{array}$ \\
\hline Wet localities & $\begin{array}{l}\text { Cussonia, Anthocleista, Drosera, Gunnera, Myrio- } \\
\text { phyllum, Nuphar, Plantago, Phragmites type, } \\
\text { Oxygonum-Polygonum, Clematis type, Solanum, } \\
\text { Typha, Urticaceae }\end{array}$ \\
\hline
\end{tabular}

\section{Conclusions}

Deep-sea sediments from IODP Site U1479 retrieved from SW of Cape Town provide a $300 \mathrm{kyr}$ long record of pollen, spores and micro-charcoal from the Greater Cape Floristic Region, indicating developments in fynbos, succulent vegetation, thicket and forest over the course of three glacialinterglacial cycles. The micro-charcoal record suggests that fires occurred more in fynbos than in other vegetation types of the GCFR. Our data indicate a substantial change in vegetation during the terminations of glacial periods. During sea level lowstands, the vegetation on the western part of the PAP would have consisted of asteraceous and ericaceous fynbos including renosterveld as well as thicket and woodland. Our results corroborate the vegetation modeling for the PAP during the last glacial maximum. However, we also infer ex- 
tension of Podocarpaceae forest during parts of MIS 7 and MIS 5-4. The record exhibits relatively little grass pollen, which is difficult to reconcile with fossils of grazers found at Pleistocene paleontological and archeological glacial sites across the GCFR.

Precession variability of the Podocarpaceae record, in particular, indicates increased summer rain and extension of the year-round rainfall zone in southernmost Africa at the cost of the winter rainfall zone during phases of maximum precession, when local summer insolation was high and the latitudinal insolation gradient in austral winter was weak. While the pollen accumulation rates of most taxa only exhibit a precessional rhythm, those of Poaceae, Restionaceae and Stoebe-Elytropappus type show both precession- and obliquity-related variability. This differentiation suggests a heterogeneous response of different vegetation types in the GCFR to global climatic changes.

Comparison with the Pliocene (Piacenzian) record of the same site indicates that the Pleistocene-Holocene winter rainfall zone decreased in size compared to the Pliocene. Reduced extension of the winter rainfall zone along the south coast could have been the result of weak westerlies in combination with cool SST, which decreased precipitation during winter. However, insolation forcing and precession variability remained drivers of rainfall distribution and seasonality. The large sea level fluctuations of the late Pleistocene intermittently exposed the Paleo-Agulhas Plain but seemingly did not alter the rainfall patterns.

Data availability. Data are archived at https://doi.pangaea.de/10. 1594/PANGAEA.930614 (Dupont, 2021).

Supplement. The supplement related to this article is available online at: https://doi.org/10.5194/cp-18-1-2022-supplement.

Author contributions. LMD designed the study, carried out the palynological analysis and wrote the draft. CC carried out the isotope analysis and constructed the age model. XZ carried out the palynological analysis of the Pliocene part. JTF wrote most of Sect. 5.3. DB contributed archeological expertise. All authors contributed to the discussion and the final paper.

Competing interests. The contact author has declared that neither they nor their co-authors have any competing interests.

Disclaimer. Publisher's note: Copernicus Publications remains neutral with regard to jurisdictional claims in published maps and institutional affiliations.
Acknowledgements. We thank Nikolaos Ioannidis for his help with the palynological preparations.

Financial support. This research has been supported by the Deutsche Forschungsgemeinschaft (grant no. DU211/7) and the National Science Foundation (grant no. 1826666).

The article processing charges for this open-access publication were covered by the University of Bremen.

Review statement. This paper was edited by Anne-Laure Daniau and reviewed by Dunia H. Urrego and one anonymous referee.

\section{References}

Avery, D. M.: Micromammals as palaeoenvironmental indicators and an interpretation of the late Quaternary in the southern Cape Province, South Africa, Ann. S. Afr. Mus., 85, 183-274, 1982.

Bar-Matthews, M., Marean, C. W., Jacobs, Z., Karkanas, P., Fischer, E. C., Herries, A. I. R., Brown, K., Williams, H.-M., Bernatchez, J., Ayalon, A., and Nilssen, P. J.: A high resolution and continuous isotopic speleothem record of paleoclimate and paleoenvironment from 90 to $53 \mathrm{ka}$ from Pinnacle Point on the south coast of South Africa, Quaternary Sci. Rev., 29, 2131-2145, https://doi.org/10.1016/j.quascirev.2010.05.009, 2010.

Bereiter, B., Eggleston, S., Schmitt, J., Nehrbass-Ahles, C., Stocker, T. F., Fischer, H., Kipfstuhl, S. and Chappelaz, J.: Revision of the EPICA Dome $\mathrm{C} \mathrm{CO}_{2}$ record from 800 to $600 \mathrm{kyr}$ before present, Geophys. Res. Lett., 42, 542-549, https://doi.org/10.1002/2014GL061957, 2015.

Bintanja, R., Van der Wal, R. S., and Oerlemans, J.: Modelled atmospheric temperatures and global sea levels over the past million years, Nature, 437, 125-128, https://doi.org/10.1038/nature03975, 2005.

Bonnefille, R. and Riollet, G.: Pollens des savanes d'Afrique orientale, Éditions du Centre National de la Recherche Scientifique, Paris, France, 978-2222024972, 1980.

Bosmans, J., Drijfhout, S. S., Tuenter, E., Hilgen, F., and Lourens, L.: Response of the North African summer monsoon to precession and obliquity forcings in the EC-Earth GCM, Clim. Dynam., 44, 279-297, https://doi.org/10.1007/s00382-014-2260-z, 2015.

Boyer, T. P., Antonov, J. I., Baranova, O. K., Coleman, C., Garcia, H. E., Grodsky, A., Johnson, D. R., Locarnini, R. A., Mishonov, A. V., O'Brien, T. D., Paver, C. R., Reagan, J. R., Seidov, D., Smolyar, I. V., and Zweng, M. M.: World Ocean Database 2013, in: NOAA Atlas NESDIS, 72, edited by: Levitus, S. and Mishonov, A., 209 pp., https://doi.org/10.7289/V5NZ85MT, 2013.

Braun, K., Bar-Matthews, M., Matthews, A., Ayalon, A., Zilberman, T., Cowling, R. M., Fisher, E. C., Herries, A. I. R., Brink, J. S., and Marean, C. W.: Late Pleistocene records of speleothem stable isotopic compositions from Pinnacle Point on the South African south coast, Quaternary Res., 91, 265-288, https://doi.org/10.1017/qua.2018.61, 2019.

Braun, K., Bar-Matthews, M., Matthews, A., Ayalon, A., Cowling, R. M., Karkanas, P., Fisher, E. C., Dyez, K., Zilberman, T., and Marean, C. W.: Comparison of climate and environ- 
ment on the edge of the Palaeo-Agulhas Plain to the Little Karoo (South Africa) in Marine Isotope Stages 5-3 as indicated by speleothems, Quaternary Sci. Rev., 235, 105803, https://doi.org/10.1016/j.quascirev.2019.06.025, 2020.

Caley, T., Kim, J.-H., Malaizé, B., Giraudeau, J., Laepple, T., Caillon, N., Charlier, K., Rebaubier, H., Rossignol, L., Castañeda, I. S., Schouten, S., and Sinninghe Damsté, J. S.: Highlatitude obliquity as a dominant forcing in the Agulhas current system, Clim. Past, 7, 1285-1296, https://doi.org/10.5194/cp-71285-2011, 2011.

Caley, T., Extier, T., Collins, J. A., Schefuß, E., Dupont, L., Malaizé, B., Rossignol, L., Souron, A., Mcclymont, E. L., Jiminez-Espejo, F. J., García-Comas, C., Eynaud, F., Martinez, P., Roche, D. M., Jorry, S. J., Charlier, K., Wary, M., Gouvers, P.-Y., Billy, I., and Giraudeau, J.: A two-million-year-long hydroclimatic context for hominin evolution in southeastern Africa, Nature, 560, 76-79, https://doi.org/10.1038/s41586-018-0309-6, 2018.

Cartwright, C. R.: Identifying the woody resources of Diepkloof Rock Shelter (South Africa) using scanning electron microscopy of the MSA wood charcoal assemblages, J. Archaeol. Sci., 40, 3463-3474, https://doi.org/10.1016/j.jas.2012.12.031, 2013.

Cartwright, C. R. and Parkington, J.: The wood charcoal assemblages from Elands Bay Cave, southwestern Cape: principles, procedures and preliminary interpretation, S. Afr. Archaeol. Bull., 52, 59-72, 1997.

Cawthra, H. C., Cowling, R. M., Andò, S., and Marean, C. W.: Geological and soil maps of the Palaeo-Agulhas Plain for the Last Glacial Maximum, Quaternary Sci. Rev., 235, 105858, https://doi.org/10.1016/j.quascirev.2019.07.040, 2020.

Chase, B. M.: South African palaeoenvironments during marine oxygen isotope stage 4: a context for the Howiesons Poort and Still Bay industries, J. Archaeol. Sci., 37, 1359-1366, https://doi.org/10.1016/j.jas.2009.12.040, 2010.

Chase, B. M. and Meadows, M. E.: Late Quaternary dynamics of southern Africa's winter rainfall zone, Earth-Sci. Rev., 84, 103138, https://doi.org/10.1016/j.earscirev.2007.06.002, 2007.

Chase, B. M. and Quick, L. J.: Influence of Agulhas forcing of Holocene climate change in South Africa's southern Cape, Quaternary Res., 90, 303-309, https://doi.org/10.1017/qua.2018.57, 2018.

Chase, B. M., Quick, L. J., Meadows, M. E., Scott, L., Thomas, D. S. G., and Reimer, P. J.: Late glacial interhemispheric climate dynamics revealed in South African hyrax middens, Geology, 39, 19-22, https://doi.org/10.1130/G31129.1, 2011.

Chase, B. M., Scott, L., Meadows, M. E., Gil-Romery, G., Boom, A., Carr, A. S., Reimer, P. J., Truc, L., Valsecchi, V., and Quick, L. J.: Rock hyrax middens: A palaeoenvironmental archive for southern African drylands, Quaternary Sci. Rev., 56, 107-125, https://doi.org/10.1016/j.quascirev.2012.08.018, 2012.

Chase, B. M., Boom, A., Carr, A. S., Meadows, M. E., and Reimer, P. J.: Holocene climate change in southernmost South Africa: rock hyrax middens record shifts in the southern westerlies, Quaternary Sci. Rev., 82, 199-205, https://doi.org/10.1016/j.quascirev.2013.10.018, 2013.

Chase, B. M., Chevalier, M., Boom, A., and Carr, A. S.: The dynamic relationship between temperate and tropical circulation systems across South Africa since the last glacial maximum, Quaternary Sci. Rev., 174, 54-62, https://doi.org/10.1016/j.quascirev.2017.08.011, 2017.
Chase, B. M., Faith, J. T., Mackay, A., Chevalier, M., Carr, A. S., Boom, A., Lim, S., and Reimer, P. J.: Climatic controls on Later Stone Age human adaptation in Africa's southern Cape, J. Hum. Evol., 114, 35-44, https://doi.org/10.1016/j.jhevol.2017.09.006, 2018.

Chase, B. M., Niedermeyer, E. M., Boom, A., Carr, A. S., Chevalier, M., He, F., Meadows, M. M., Ogle, N., and Reimer, P. J.: Orbital controls on Namib Desert hydroclimate over the past 50,000 years, Geology, 47, 867-871, https://doi.org/10.1130/G46334.1, 2019.

Cheng, H., Edwards, R. L., Broecker, W. S., Denton, G. H., Kong, X., Wang, Y., Hang, R., and Wang, X.: Ice Age terminations, Science, 326, 248-252, https://doi.org/10.1126/science.1177840, 2009.

Cleghorn, N., Potts, A. J., and Cawthra, H. C.: The Palaeo-Agulhas Plain: A lost world and extinct ecosystem (preface), Quaternary Sci. Rev., 235, 106308, https://doi.org/10.1016/j.quascirev.2020.106308, 2020.

Copeland, S. R., Cawthra, H. C., Fisher, E., Lee-Thorp, J., Cowling, R. M., Le Roux, P. J., Hodgkins, J., and Marean, C. W.: Strontium isotope investigation of ungulate movement patterns on the Pleistocene Paleo-Agulhas Plain of the Greater Cape Floristic Region, South Africa, Quaternary Sci. Rev., 141, 6584, https://doi.org/10.1016/j.quascirev.2016.04.002, 2016.

Cowling, R. M., Cartwright, C. R., Parkington, J. E., and Allsopp, J. C.: Fossil wood charcoal assemblages from Elands Bay cave, South Africa: implications from Late Quaternary vegetation and climates in the winter-rainfall fynbos biome, J. Biogeogr., 26, 367-378, https://doi.org/10.1046/j.1365-2699.1999.00275.x, 1999.

Cowling, R. M., Potts, A. J., Franklin, J., Midgley, G. F., Engelbrecht, F., and Maren, C. W.: Describing a drowned Pleistocene ecosystem: Last Glacial Maximum vegetation reconstruction of the Palaeo-Agulhas Plain, Quaternary Sci. Rev., 235, 105866 , https://doi.org/10.1016/j.quascirev.2019.105866, 2020.

Daniau, A.-L., Sánchez Goni, M. F., Martinez, P., Urrego, D. H., Bout-Roumazeilles, V., Desprat, S., and Marlon, J. R.: Orbital-scale climate forcing of grassland burning in southern Africa, P. Natl. Acad. Sci. USA, 110, 5069-5073, https://doi.org/10.1073/pnas.1214292110, 2013.

Davis, B. S. and Brewer, S.: Orbital forcing and role of the latitudinal insolation/temperature gradient, Clim. Dynam., 32, 143-165, https://doi.org/10.1007/s00382-008-0480-9, 2009.

Dupont, L. M.: Orbital scale vegetation change in Africa, Quaternary Sci. Rev., 30, 3589-3602, https://doi.org/10.1016/j.quascirev.2011.09.019, 2011.

Dupont, L. M.: Pollen and spores and micro-charcoal of IODP Site 361-U1479 (0-300 ka), PANGAEA [data set], https://doi. pangaea.de/10.1594/PANGAEA.930614, 2021.

Dupont, L. M., Linder, H. P., Rommerskirchen, F., and Schefuß, E.: Climate-driven rampant speciation of the Cape flora, J. Biogeogr., 38, 1059-1068, https://doi.org/10.1111/j.13652699.2011.02476.x, 2011.

Dupont, L. M., Caley, T., and Castañeda, I. S.: Effects of atmospheric $\mathrm{CO}_{2}$ variability of the past $800 \mathrm{kyr}$ on the biomes of southeast Africa, Clim. Past, 15, 1083-1097, https://doi.org/10.5194/cp-15-1083-2019, 2019.

Engelbrecht, C. J., Landman, W. A., Engelbrecht, F. A., and Malherbe, J.: A synoptic decomposition of rainfall over the Cape 
south coast of South Africa, Clim. Dynam., 44, 2589-2607, https://doi.org/10.1007/s00382-014-2230-5, 2015.

Engelbrecht, F. A., Maren, C. W., Cowling, R. M., Engelbrecht, C., Neumann, F. H., Scott, L., Nkoana, R., O'Neal, D., Fisher, E., Shook, E., Franklin, J., Thatcher, M., McGregor, J. L., Van Der Merwe, J., Dedekind, Z., and Difford, M.: Downscaling Last Glacial Maximum climate over southern Africa, Quaternary Sci. Rev., 226, 105879, https://doi.org/10.1016/j.quascirev.2019.105879, 2019.

Esper, O., Versteegh, G. J. M., Zonneveld, K. A. F., and Willems, H.: A palynological reconstruction of the Agulhas Retroflection (South Atlantic Ocean) during the Late Quaternary, Global Planet. Change, 41, 31-62, https://doi.org/10.1016/j.gloplacha.2003.10.002, 2004.

Esteban, I., Marean, C. W., Fischer, E., Karkanas, P., Cabanes, D., and Albert, R. M.: Phytoliths as an indicator of early modern humans plant gathering strategies, fire fuel and site occupation intensity during the Middle Stone Age at Pinnacle Point 5-6 (south coast, South Africa), PLOS ONE, 13, e0198558, https://doi.org/10.1371/journal.pone.0198558, 2018.

Esteban, I., Marean, C. W., Cowling, R. M., Fischer, E., Cabanes, D., and Albert, R. M.: Palaeoenvironments and plant availability during MIS 6 to MIS 3 on the edge of the Palaeo-Agulhas Plain (south coast, South Africa) as indicated by phytolith analysis at Pinnacle Point, Quaternary Sci. Rev., 235, 105667, https://doi.org/10.1016/j.quascirev.2019.02.022, 2020.

Faith, J. T.: Palaeozoological insights into management options for a threatened mammal: southern Africa's Cape mountain zebra (Equus zebra zebra), Divers. Distrib., 18, 438-447, https://doi.org/10.1111/j.1472-4642.2011.00841.x, 2012.

Faith, J. T.: Ungulate diversity and precipitation history since the Last Glacial Maximum in the Western Cape, South Africa, Quaternary Sci. Rev., 68, 191-199, https://doi.org/10.1016/j.quascirev.2013.02.016, 2013.

Faith, J. T. and Thompson, J. C.: Fossil evidence for seasonal calving and migration of extinct blue antelope (Hippotragus leucophaeus) in southern Africa, J. Biogeogr., 40, 2108-2118, https://doi.org/10.1111/jbi.12154, 2013.

Faith, J. T., Chase, B. M., and Avery, D. M.: Late Quaternary micromammals and the precipitation history of the southern Cape, South Africa, Quaternary Res., 91, 848-860, https://doi.org/10.1017/qua.2018.105, 2019.

Forrest, F. L., Stynder, D. D., Bishop, L. C., Levin, N. E., Lehmann, S. B., Patterson, D. B., Matthews, T., and Braun, D. R.: Zooarchaeological reconstruction of newly excavated Middle Pleistocene deposits from Elandsfontein, South Africa, J. Archaeol. Sci., 17, 19-29, https://doi.org/10.1016/j.jasrep.2017.10.034, 2018.

Hall, I. R., Hemming, S. R., Levay, L. J., and the Expedition 361 Scientists: Site U1479, Proceedings of the International Ocean Discovery Program, 361, IODP, College Station, Texas, USA, 130, https://doi.org/10.14379/iodp.proc.361.108.2017, 2017.

Hammer, Ø., Harper, D. A. T., and Ryan, P. D.: PAST: Paleontological Statistics Software Package for Education and Data Analysis, Palaeontol. Electron., 4, 1-9, 2001.

Hammer, Ø.: PAST, PAleontological STatistics Version 4.02, Reference Manual, National History Museum, University of Oslo, Norway, 280 pp., available at: https://www.nhm.uio.no/english/ research/infrastructure/past/downloads/past4manual.pdf (last access: 21 March 2020), 1999-2021.

Henshilwood, C. S., Sealy, J. C., Yates, R., Cruz-Uribe, K., Goldberg, P., Grine, F. E., Klein, R. G., Poggenpoel, C., Van Niekerk, K., and Watts, I.: Blombos Cave, Southern Cape, South Africa: Preliminary report on the 1992-1999 excavations of the Middle Stone Age levels, J. Archaeol. Sci., 28, 421-448, https://doi.org/10.1006/jasc.2000.0638, 2001.

Henshilwood, C. S., D’Errico, F., Yates, R., Jacobs, Z., Tribolo, C., Duller, G. A. T., Mercier, N., Sealy, J. C., Valladas, H., Watts, I., and Wintle, A. G.: Emergence of modern human behavior: Middle Stone Age engravings from South Africa, Science, 295, 1278-1280, https://doi.org/10.1126/science.1067575, 2002.

Henshilwood, C. S., D'Errico, F., Van Niekerk, K. L., Coquinot, Y., Jacobs, Z., Lauritzen, S.-E., Menu, M., and GarciaMoreno, R.: A 100,000-year-old ochre-processing workshop at Blombos Cave, South Africa, Science, 334, 219-222, https://doi.org/10.1126/science.1211535, 2011.

Hijmans, R., Cameron, S. E., Parra, J. L., Jones, P. G., and Jarvis, A.: Very high resolution interpolated climate surfaces for global land areas, Int. J. Climatol., 25, 1965-1978, https://doi.org/10.1002/joc.1276, 2005.

Hines, S. K. V., Bolge, L., Goldstein, S. L., Charles, C. D., Hall, I. R., and Hemming, S. R.: Little change in ice age water mass structure from Cape Basin benthic neodymium and carbon isotopes, Paleoceanogr. Paleoclimatol., 36, e2021PA004281, https://doi.org/10.1029/2021PA004281, 2021.

Hodgkins, J., Marean, C. W., Venter, J. A., Richardson, L., Roberts, P., Zech, J., Difford, M., Copeland, S. R., Orr, C. M., Keller, H. M., Fahey, B. P., and Lee-Thorp, J. A.: An isotopic test of the seasonal migration hypothesis for large grazing ungulates inhabiting the Palaeo-Agulhas Plain, Quaternary Sci. Rev., 235, 106221, https://doi.org/10.1016/j.quascirev.2020.106221, 2020.

Howell, P., Pisias, N., Ballance, J., Baughman, J., and Ochs, L.: ARAND Time-Series Analysis Software, Brown University, Providence, RI, USA, available at: https://github.com/ jesstierney/arand (last access: 5 November 2020), 2006.

Jury, M. R., Valentine, H. R., and Lutjeharms, J. R. E.: Influence of the Agulhas Current on Summer Rainfall along the Southeast Coast of South Africa, J. Appl. Meteorol., 32, 1282-1287, https://doi.org/10.1175/15200450(1993)032<1282:IOTACO>2.0.CO;2, 2015.

Klein, R. G.: The late Quaternary mammalian fauna of Nelson Bay Cave (Cape Province, South Africa): its implications for megafaunal extinctions and environmental and cultural change, Quaternary Res., 2, 135-142, https://doi.org/10.1016/00335894(72)90034-8, 1972.

Klein, R. G.: Paleoanthropological implications of the nonarcheological bone assemblage from Swartklip I, South-Western Cape Province, South Africa, Quaternary Res., 5, 275-288, https://doi.org/10.1016/0033-5894(75)90029-0, 1975.

Klein, R. G.: The mammalian fauna of the Klasies River Mouth sites, southern Cape Province, South Africa, S. Afr. Archaeol. Bull., 31, 75-98, https://doi.org/10.2307/3887730, 1976.

Klein, R. G.: Palaeoenvironmental implications of Quaternary large mammals in the fynbos region, in: Fynbos Palaeoecology, A Preliminary Synthesis, edited by: Deacon, H. J., Hendey, Q. B. and Lambrechts, J. J. N., South African National Scientific Pro- 
grammes Report No. 75, Mills Litho, Cape Town, South Africa, 116-138, 079-8829532, 1983.

Klein, R. G.: The Fauna and Overall Interpretation of the "Cutting 10" Acheulean Site at Elandsfontein (Hopefield), Southwestern Cape Province, South Africa, Quaternary Res., 10, 6983, https://doi.org/10.1016/0033-5894(78)90014-5, 1978.

Klein, R. G. and Cruz-Uribe, K.: Large mammal and tortoise bones from Elands Bay Cave and nearby sites, western cape Province, South Africa, in: Papers in the prehistory of the Western Cape, South Africa, BAR International Series 322, edited by: Parkington, J. E. and Hall, M., Cambridge, UK, 132-163, 0860-544257, 1987.

Klein, R. G. and Cruz-Uribe, K.: The mammalian fauna associated with an archaic hominin skullcap and later Acheulean artifacts at Elandsfontein, Western Cape Province, South Africa, J. Hum. Evol., 52, 164-186, https://doi.org/10.1006/jhev.1999.0355, 2000.

Klein, R. G. and Cruz-Uribe, K.: Large mammal and tortoise bones from Elands Bay Cave (South Africa): implications for Later Stone Age environment and ecology, Southern Afr. Humanit., 29, 259-282, 2016

Kraaij, T., Engelbrecht, F., Franklin, J., and Cowling, R. M.: A fiery past: A comparison of glacial and contemporary fire regimes on the Palaeo-Agulhas Plain, Cape Floristic Region, Quaternary Sci. Rev., 235, 106059, https://doi.org/10.1016/j.quascirev.2019.106059, 2020.

Kutzbach, J. E., Liu, X., and Liu, Z.: Simulation of the evolutionary response of global summer monsoons to orbital forcing over the past 280,000 years, Clim. Dynam., 30, 567-579, https://doi.org/10.1007/s00382-007-0308-z, 2008.

Laskar, J., Robutel, P., Joutel, F., Gastineau, M., Correia, A. C. M., and Levrard, B.: A long-term numerical solution for the insolation quantities of the Earth, Astron. Astrophys., 428, 261-285, https://doi.org/10.1051/0004-6361:20041335, 2004.

Lin, L., Khider, D., Lisiecki, L. E., and Lawrence, C. E.: Probabilistic Sequence Alignment of Stratigraphic Records, Paleoceanography, 29, 976-989, https://doi.org/10.1002/2014PA002713, 2014.

Linder, H. P.: The radiation of the Cape Flora, southern Africa, Biol. Rev., 78, 597-638, https://doi.org/10.1017/S1464793103006171, 2003.

Lisiecki, L. E. and Raymo, M. E.: A Pliocene-Pleistocene stack of 57 globally distributed benthic $\delta^{18} \mathrm{O}$ records, Paleoceanography, 20, PA1003, https://doi.org/10.1029/2004PA001071, 2005.

Mackay, A., Stewart, B. A., and Chase, B. M.: Coalescence and fragmentation in the late Pleistocene archaeology of southernmost Africa, J. Hum. Evol., 72, 26-51, https://doi.org/10.1016/j.jhevol.2014.03.003, 2014.

Maher, L. J.: Nomograms for computing 0.95 confidence limits of pollen data, Rev. Palaeobot. Palyno., 13, 85-93, 1972.

Maher, L. J.: Statistics for microfossil concentration measurements employing samples spiked with marker grains, Rev. Palaeobo. Palyno., 32, 153-191, 1981.

Marean, C. W.: Pinnacle Point Cave 13B (Western Cape Province, South Africa) in context: the Cape Floral kingdom, shellfish, and modern human origins, J. Hum. Evol., 59, 425-443, https://doi.org/10.1016/j.jhevol.2010.07.011, 2010.

Marean, C. W., Cawthra, H. C., Cowling, R. M., Esler, K. J., Fisher, E., Milewski, A., Potts, A. J., Singels, E., and De Vynck, J.: Stone
Age people in a changing South African Greater Cape Floristic Region, in: Fynbos, Ecology, Evolution, and Conservation of a Megadiverse Region, edited by: Colville, J. F. and Verboom, G. A., Oxford University Press, Oxford, UK, 164-199, 9780198777762, 2014.

Marean, C. W., Cowling, R. M., and Franklin, J.: The PalaeoAgulhas Plain: Temporal and spatial variation in an extraordinary extinct ecosystem of the Pleistocene of the Cape Floristic Region, Quaternary Sci. Rev., 235, 106161, https://doi.org/10.1016/j.quascirev.2019.106161, 2020.

Meadows, M. E. and Sugden, J. M.: A vegetation history of the last 14000 years on the Cederberg, south-western Cape Province, S. Afr. J. Sci., 87, 34-43, 1991.

Meadows, M. N., Chase, B. M., and Seliane, M.: Holocene palaeoenvironments of the Cederberg and Swartruggens mountains, Western Cape, South Africa: Pollen and stable isotope evidence from hyrax dung middens, J. Arid Environ., 74, 786-793, https://doi.org/10.1016/j.jaridenv.2009.04.020, 2010.

Mucina, L. and Geldenhuys, C. J.: Afrotemperate, Subtropical and Azonal Forests, in: The vegetation of South Africa, Lesotho and Swaziland, edited by: Mucina, L. and Rutherford, M. C., Strelitzia 19, South African National Biodiversity Institute, Pretoria, South Africa, 585-614, 978-1919976211, 2006.

Mucina, L. and Rutherford, M. C.: The vegetation of South Africa, Lesotho and Swaziland, Strelitzia 19, South African National Biodiversity Institute, Pretoria, South Africa, 978-1919976211, 2006.

Mucina, L., Jürgens, N., Le Roux, A., Rutherford, M. C., Schmiedel, U., Esler, K. J., Powrie, L. W., Desmet, P. G., and Milton, S. J.: Succulent Karoo Biome, in: The vegetation of South Africa, Lesotho and Swaziland, edited by: Mucina, L. and Rutherford, M. C., Strelitzia 19, South African National Biodiversity Institute, Pretoria, South Africa, 221-299, 9781919976211, 2006.

Nel, T. H. and Henshilwood, C. S.: The small mammal sequence from the c. 76-72 ka Still Bay levels at Blombos Cave, South Africa - Taphonomic and palaeoecological implications for human ehaviour, PLOS ONE, 11, e0159817, https://doi.org/10.1371/journal.pone.0159817, 2016.

Nel, T. H., Wurz, S., and Henshilwood, C. S.: Small mammals from Marine Isotope Stage 5 at Klasies River, South Africa - Reconstructing the local palaeoenvironment, Quatern. Int., 471, 6-20, https://doi.org/10.1016/j.quaint.2017.08.074, 2018.

Owensby, C. E., Cochran, R. C. and Auen, L. M.: Effects of elevated carbon dioxide on forage quality for ruminants, in: Carbon Dioxide, Populations, and Communities, edited by: Körner, C. and Bazzaz, F., Academic Press, Cambridge, Massachusetts, USA, 363-371, 978-0124208704, 1996.

Parkington, J., Cartwright, C., Cowling, R. M., Baxter, A., and Meadows, M.: Palaeovegetation at the last glacial maximum in the western Cape, South Africa: wood charcoal and pollen evidence from Elands Bay Cave, S. Afr. J. Sci., 96, 543-546, 2000.

Partridge, T. C., DeMenocal, P. B., Lorentz, S. A., Paiker, M. J., and Vogel, J. C.: Orbital forcing of climate over South Africa: a 200,000-year rainfall record from the Pretoria Saltpan, Quaternary Sci. Rev., 16, 1125-1133, 1997.

Past Interglacials Working Group of PAGES: Interglacials of the last 800,000 years, Rev. Geophys., 54, 162-219, https://doi.org/10.1002/2015RG000482, 2016. 
Petschick, R., Kuhn, G., and Gingele, F.: Clay mineral distribution in surface sediments of the South Atlantic: sources, transport, and relation to oceanography, Mar. Geol., 130, 203-229, https://doi.org/10.1016/0025-3227(95)00148-4, 1996.

Quick, L. J., Chase, B. M., Meadows, M. E., Scott, L., and Reimer, P. J.: A $195 \mathrm{kyr}$ vegetation history from the central Cederberg Mountains, South Africa: Palynological evidence from rock hyrax middens, Palaeogeogr. Palaeocl., 309, 253-270, https://doi.org/10.1016/j.palaeo.2011.06.008, 2011.

Quick, L. J., Carr, A. S., Meadows, M. E., Boom, A., Bateman, M. D., Roberts, D. L., Reimer, P. J., and Chase, B. M.: A late Pleistocene-Holocene multi-proxy record of palaeoenvironmental change from Still Bay, southern Cape Coast, South Africa, J. Quaternary Sci., 30, 870-885, https://doi.org/10.1002/jqs.2825, 2015.

Quick, L. J., Meadows, M. E., Bateman, M. B., Kirsten, K. L., Mäusbacher, R., Haberzettl, T., and Chase, B. M.: Vegetation and climate dynamics during the last glacial period in the fynbos-afrotemperate forest ecotone, southern Cape, South Africa, Quatern. Int., 404, 136-149, https://doi.org/10.1016/j.quaint.2015.08.027, 2016.

Reason, C. J. C. and Mulenga, H.: Relationships between South African rainfall and SST anomalies in the Southwest Indian Ocean, Int. J. Climatol., 19, 1651-1673, https://doi.org/10.1002/(SICI)10970088(199912)19:15<1651::AID-JOC439>3.0.CO;2-U, 1999.

Reason, C. J. C., Jagadheesha, D., and Tadross, M.: A model investigation of inter-annual winter rainfall variability over southwestern South Africa and associated ocean-atmosphere interaction, S. Afr. J. Sci., 99, 75-80, 2003.

Rebelo, A. G., Boucher, C., Helme, N., Mucina, L., and Rutherford, M. C.: Fynbos Biome, in: The vegetation of South Africa, Lesotho and Swaziland, edited by: Mucina, L. and Rutherford, M. C., Strelitzia 19, South African National Biodiversity Institute, Pretoria, South Africa, 53-219, 978-1919976211, 2006.

Rector, A. L. and Reed, K. E.: Middle and Late Pleistocene faunas of Pinnacle Point and their paleoecological implications, J. Hum. Evol., 59, 340-357, https://doi.org/10.1016/j.jhevol.2010.07.002, 2010.

Schüler, L. and Hemp, A.: Atlas of pollen and spores and their parent taxa of Mt Kilimanjaro and tropical East Africa, Quaternary Int., 425, 301-386, https://doi.org/10.1016/j.quaint.2016.07.038, 2016.

Schulz, M. and Mudelsee, M.: REDFIT: estimating red-noise spectra directly from unevenly spaced paleoclimatic time series, Comput. Geosci., 28, 421-426, https://doi.org/10.1016/S00983004(01)00044-9, 2002.

Scott, L.: Late Quaternary fossil pollen grains from the Transvaal, South Africa, Rev. Palaeobot. Palyno., 36, 241-278, https://doi.org/10.1016/0034-6667(82)90022-7, 1982.

Scott, L. and Neumann, F. H.: Pollen-interpreted palaeoenvironments associated with the Middle and Late Pleistocene peopling of Southern Africa, Quaternary Int., 495, 169-184, https://doi.org/10.1016/j.quaint.2018.02.036, 2018.

Scott, L. and Woodborne, S.: Vegetation history inferred from pollen in Late Quaternary faecal deposits (hyraceum) in the Cape winter-rain region and its bearing on past climates in South Africa, Quaternary Sci. Rev., 26, 941-953, https://doi.org/10.1016/j.quascirev.2006.12.012, 2007a.
Scott, L. and Woodborne, S.: Pollen analysis and dating of Late Quaternary faecal deposits (hyraceum) in the Cederberg, Western Cape, South Africa, Rev. Palaeobot. Palyno., 144, 123-134, https://doi.org/10.1016/j.revpalbo.2006.07.004, 2007b.

Sealy, J., Lee-Thorp, L., Loftus, E., Faith, J. T., and Marean, C. W.: Late Quaternary environmental change in the Southern Cape, South Africa, from stable carbon and oxygen isotopes in faunal tooth enamel from Boomplaas Cave, J. Quaternary Sci., 31, 919927, https://doi.org/10.1002/jqs.2916, 2016.

Sealy, J., Naidoo, N., Hare, V. J., Brunton, S., and Faith, J. T.: Climate and ecology of the Palaeo-Agulhas Plain from stable carbon and oxygen isotopes in bovid tooth enamel from Nelson Bay Cave, South Africa, Quaternary Sci. Rev., 235, 105974, https://doi.org/10.1016/j.quascirev.2019.105974, 2020.

Simon, M. H., Ziegler, M., Bosmans, J., Barker, S., Reason, C. J. C., and Hall, I. R.: Eastern South African hydroclimate over the past 270,000 years, Sci. Rep.-UK, 5, 18153, https://doi.org/10.1038/srep18153, 2015.

Stynder, D. D.: The diets of ungulates from the hominid fossil-bearing site of Elandsfontein, Western Cape, South Africa, Quaternary Res., 71, 62-70, https://doi.org/10.1016/j.yqres.2008.06.003, 2009.

Talma, A. S. and Vogel, J. C.: Late Quaternary paleotemperatures derived from a speleothem from Cango Caves, Cape Province, South Africa, Quaternary Res., 37, 203-213, 1992.

Thackeray, F. J.: Late Quaternary micromammals and the precipitation history of the southern Cape, South Africa - comment on the published paper by Faith et al., Quaternary Res. (2019), Vol. 91, 848-860, Quaternary Res., 95, 154-156, https://doi.org/10.1017/qua.2019.77, 2020.

Tyson, P. D. and Preston-Whyte, R. A.: The weather and climate of Southern Africa, Oxford University Press, Cape Town, South Africa, 396 pp., 978-0195718065, 2000.

Urrego, D. H., Sánchez Goñi, M. F., Daniau, A.-L., Lechevrel, S., and Hanquiez, V.: Increased aridity in southwestern Africa during the warmest periods of the last interglacial, Clim. Past, 11, 1417-1431, https://doi.org/10.5194/cp-11-1417-2015, 2015.

Valsecchi, V., Chase, B. M., Singgsby, J. A., Carr, A. S., Quick, L. J., Meadows, M. E., Cheddadi, R., and Reimer, P. J.: A high resolution 15,600-year pollen and microcharcoal record from the Cederberg Mountains, South Africa, Palaeogeogr., Palaeocl., 387, 6-16, https://doi.org/10.1016/j.palaeo.2013.07.009, 2013.

Whitlock, C., Higuera, P., McWethy, D. B., and Briles, C. E.: Paleoecological perspectives on fire ecology: Revisiting the fire-regime concept, Open Ecol. J., 3, 6-23, https://doi.org/10.2174/1874213001003020006, 2010.

Williams, H. M., Lee-Thorp, J. A., Matthews, T., and Maren, C. W.: Micromammal and macromammal stable isotopes from a MIS 6 fossil hyena den (Pinnacle Point site 30, south coast, South Africa) reveal, differences in relative contribution of $\mathrm{C}_{4}$ grasses to local and regional palaeovegetation on the Palaeo-Agulhas Plain, Quaternary Sci. Rev., 235, 106201, https://doi.org/10.1016/j.quascirev.2020.106201, 2020.

Zhao, X., Dupont, L., Meadows, M. E., and Wefer, G.: Pollen distribution in the marine surface sediments of the mudbelt along the west coast of South Africa, Quaternary Int., 404, 44-56, https://doi.org/10.1016/j.quaint.2015.09.032, 2016.

Zhao, X., Koutsodendris, A., Caley, T., and Dupont, L. M.: Hydroclimate change in subtropical South Africa during the Mid- 
Piacenzian Warm Period, Quaternary Sci. Rev., 249, 106643, https://doi.org/10.1016/j.quascirev.2020.106643, 2020. 